\title{
Análisis de Hentai desde una perspectiva feminista: grietas en una reproducción patriarcal
}

Belén García Villena

Directora: Ana Alcázar Campos

Universidad de Granada

Facultad de Trabajo Social

Directora de apoyo: Eva Fodor

Central European University

Department of Gender Studies

Granada, junio 2012 


\title{
Análisis de Hentai desde una perspectiva feminista: grietas en una reproducción patriarcal
}

\author{
Belén García Villena
}

Directora: Ana Alcázar Campos

Universidad de Granada

Facultad de Trabajo Social

Directora de apoyo: Eva Fodor

Central European University

Department of Gender Studies

Granada, junio 2012 


\section{Resumen}

Esta investigación final de máster se centra en la temática de la sexualidad a través de un determinado hilo conductor, el Hentai. Por una parte, analizo a nivel personal mi relación con este material, a través del método autoetnográfico y cómo ello me ha servido en mi proceso de madurez sexual y qué tabúes sexuales he ido vivenciando a través de mi cuerpo y experiencias. Por otra parte, entendiendo el Hentai como un material pornográfico, realizo una contextualización sobre los posicionamientos feministas en referencia a la pornografía desde sus comienzos a finales de los 70 hasta el momento actual. El hentai o manga erótico japonés es un tipo de material que se encuentra comprendido dentro del manga -anime, novela gráfica japonesa y dibujos animados, por lo que expongo asimismo estos dos materiales artísticos en su contexto histórico- cultural en Japón y España, analizando también los subgéneros que comprenden y la representación del género en estos materiales. Por otra parte, contextualizo de manera más exhaustiva el Hentai en Japón y España. Para finalizar, realizo un análisis de tres Hentais. En estos cómics se analiza qué elementos son considerados subversivos a las prácticas sexuales tradicionales a través de los personajes principales de cada uno de ellos.

\section{Abstract}

This Master's research focus on sexuality trough an specific topic, Hentai. On one hand, I explain my personal experience with this material and how it has helped me with my process of sexual maturity with a chapter written in a autoethnographic way, explaning how I have lived sexual taboos in my own body and experiences. Taking the idea of Hentai as a pornographic material, I expose the feminist context about the pornography from the 70 s to the actual moment. Hentai or erotic manga is a subgender of manga-anime, cartoons and graphic novel, therefore I contextualize those two artistic materials in a historical context in Japan and Spain, analyzing also the subgenres which are included, and the gender representation in those materials. On the other hand I explain more exhaustively the Hentai in a Japanese and Spanish context. Furthermore, in this MA Thesis I perform an analysis of three Hentai. In those comics I analyze some elements which are considered subversive to the traditional sexual intercourses. I do it analyzing the main characters in each Hentai. 
Para Miguel, que sepa lo orgullosa que estoy de él

Para Rodrigo, que sepa que siempre voy a estar ahí

Para Samer, sine quo non 


\section{Agradecimientos}

Quisiera hacer un agradecimiento especial a mi padre y a mi madre, porque son un apoyo que siento siempre de forma segura, son el puerto no importa dónde zarpe. A mis tíos María Dolores y Jorge, por ser un apoyo sin necesidad de decirlo. A Lucía y Jorge, porque además de primos, son amigos. A mi tíos Paloma y Crístian, por ese año en Tübingen entre otras cosas. A mi prima Clara, para que en la adolescencia le ayude esta tesina. A Miguel Ángel y Marta, por acogerme tantas veces en Madrid. A Miguel Ángel porque además de tío, es una persona que me guía y me respalda.

Agradecer a mi tutora, Ana Alcázar, porque cuando estaba perdida ella me salvó. Me dio un mapa y una brújula para encontrar el camino. A mi cotutora, Eva Fodor, por embarcarse en este proyecto conmigo.

También agradecer a amigas y amigos que sin ser conscientes de ello, me han hecho mejorar, madurar y me han aportado para ser un poco mejor y más feliz. Me han dado cariño, seguridad y reconocimiento. A la gente que fue importante y formó parte de mi vida, que ya no está pero que aun así dejaron su huella.

A todas y todos aquellas y aquellos que de alguna manera $u$ otra luchamos por un cambio feminista. 


\section{Índice}

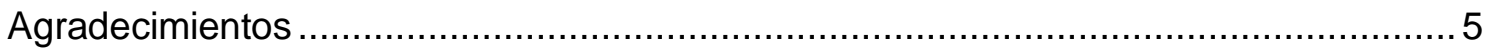

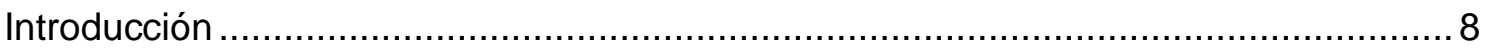

Capítulo 0: Donde todo empieza. El por qué de un análisis del Hentai desde una

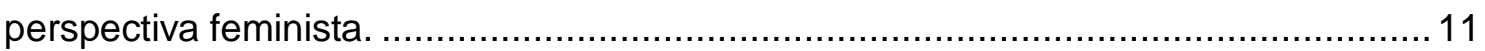

Capítulo I. Debates sobre pornografía y sexualidad desde el feminismo ….................21

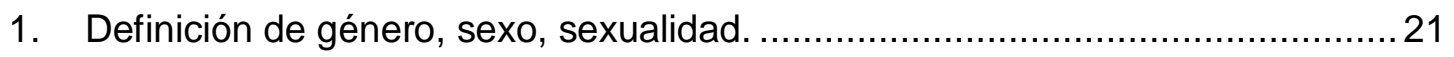

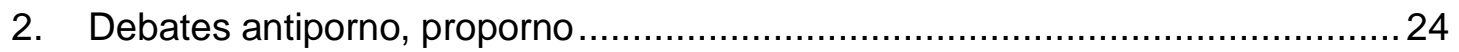

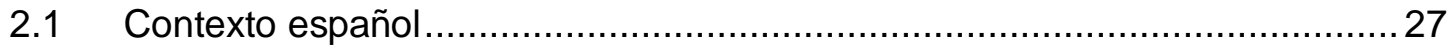

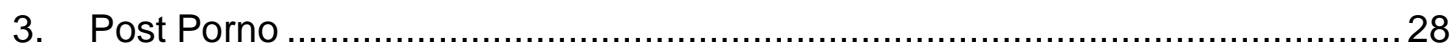

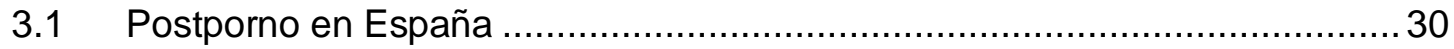

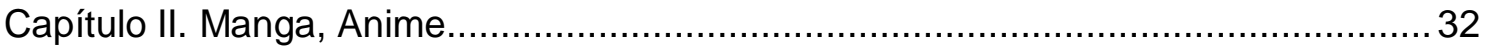

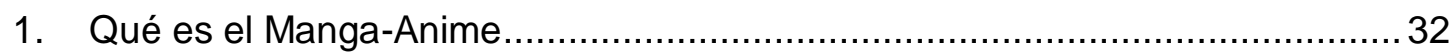

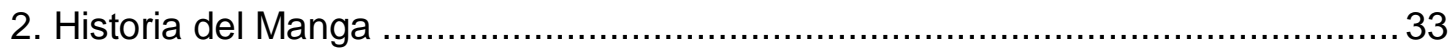

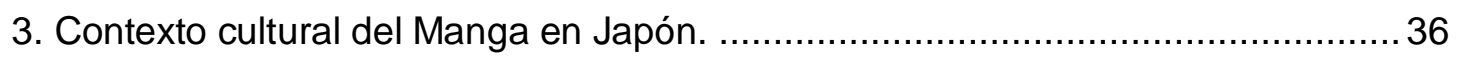

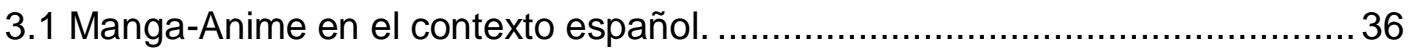

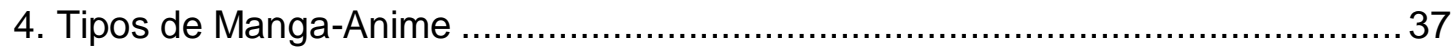

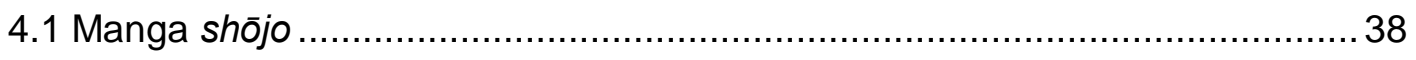

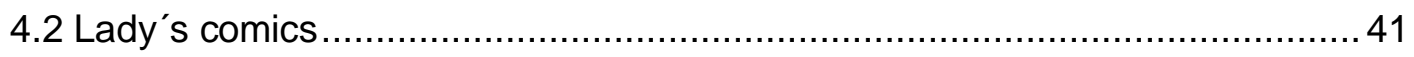

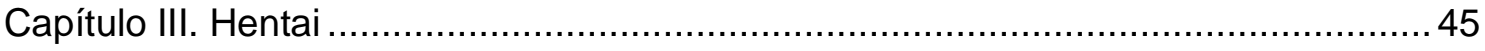

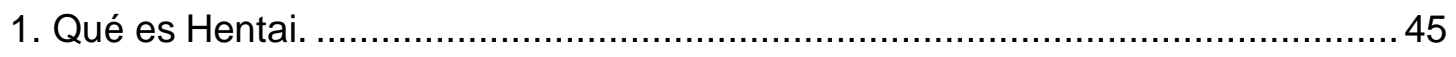

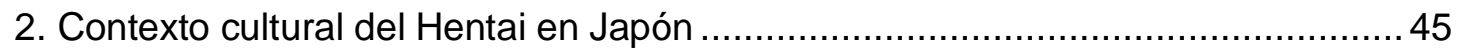

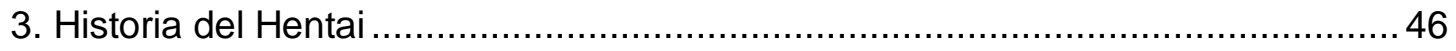

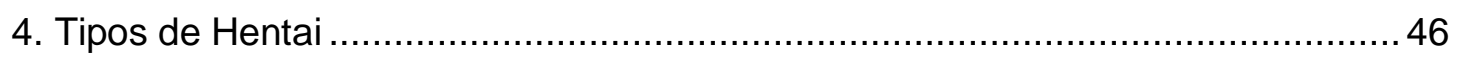

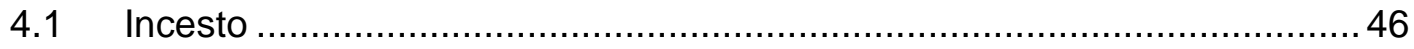




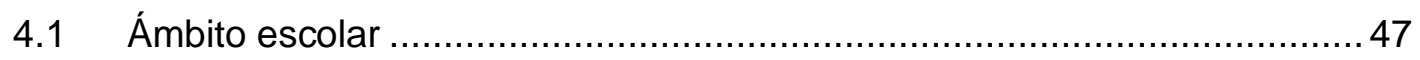

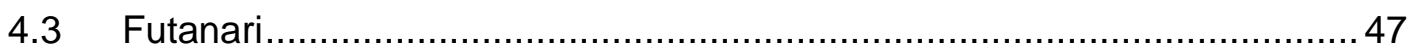

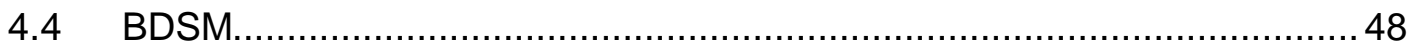

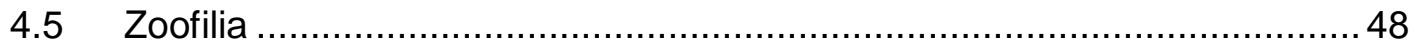

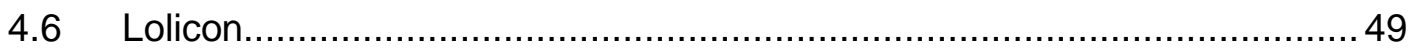

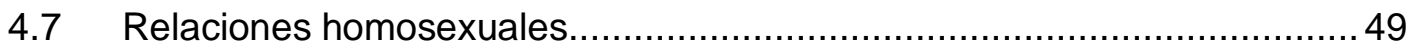

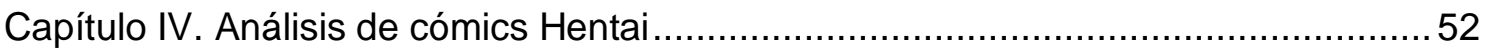

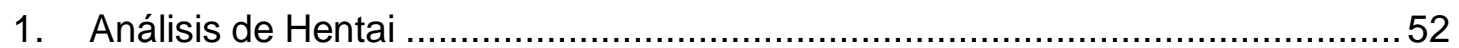

2. Tres cómics, tres opciones de fantasía sexual ...............................................53

2.1 Análisis cómic "Bondage fairies Extreme" ......................................... 53

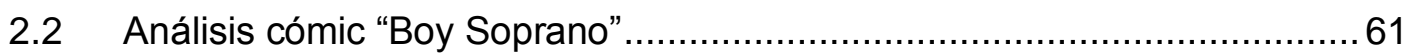

2.3 Análisis cómic "Voice of Submission II Gehenna".....................................68

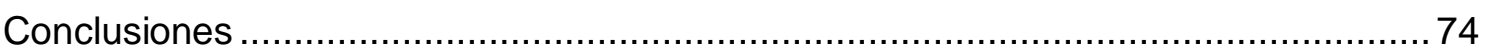

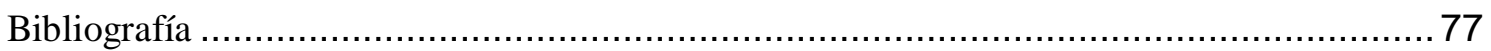




\section{Introducción}

Esta investigación se centra en el estudio de tres cómics Hentai, manga erótico. A través de ellos se analiza cómo la sexualidad es un ente construido y con prácticas sexuales aceptadas y no socialmente.

Paso a explicar la estructura de este trabajo. Divido esta investigación en varias partes diferenciadas. En la primera parte realizo un análisis autoetnográfico sobre mi vivencia de la sexualidad al que denomino capítulo cero. En el primer capítulo conceptualizo conceptos como "género", "sexualidad", "transgénero", "intersexual", además de realizar un breve repaso sobre los posicionamientos del feminismo con respecto al porno. En el capítulo dos realizo una revisión del manga y el anime, abordando su historia, contexto cultural japonés y español, y tipos de manga y anime. En el tercer capítulo expongo la temática del Hentai, definición y tipos de Hentai. En el último capítulo, el cuarto, analizo tres cómics Hentai que para mí representan tres ejemplos de distintas formas de entender la sexualidad. Finalmente, realizo unas conclusiones como apartado aglutinador de ideas de esta investigación.

Antes de entrar más a fondo en estos capítulos, me gustaría responder a la pregunta de por qué una tesis de máster centrada en esta temática. Un Hentai que forma parte de una subcultura como es el manga y el anime no muy presentes en una sociedad como la española. Al principio de elegir mi temática para escribir la tesis, me sentía un poco incómoda comentándolo, sobre todo con gente que no tengo mucha confianza. El que una persona esté escribiendo una tesina sobre manga erótico no pasa todos los días, y si es mujer todavía se le añade más morbo al asunto. Muchos de mis amigas y amigos se extrañaron y pusieron caras raras cuando les comenté que mi tesis de máster estaría centrada en el Hentai. Las preguntas fueron distintas dependiendo de la persona. Desde pensar que era una "frikie" por ver este material, hasta no saber exactamente a qué me refería (o pretender no saberlo). Otros, sobre todo amigos varones, se sonreían y mostraban especial interés por la temática desde lo que probablemente fuera un interés más movido por el morbo de que una amiga vea porno y lo diga abiertamente al ansia de conocimiento.

Ese tipo de comentarios me hicieron reafirmarme en que había elegido bien la temática. Comentarios como los descritos dejan ver el tabú e incluso el menosprecio que se tiene a ciertos aspectos de la sexualidad todavía hoy en día. 
He utilizado en dos momentos la palabra morbo, incluso de una forma despectiva, pero uno de los motivos que me movió a enfocar mi tesis de máster a esta temática, fue ése. Romper el morbo entendido como negativo, asociado al tabú de la sexualidad, algo a esconder, a avergonzarse sobre todo si eres mujer (DODSON: 1989). Pretendía romper este tabú que existe en la sociedad y también en mí.

Sé que debido al tiempo y donde se enmarca este trabajo, mi investigación no puede ser un proyecto de características ambiciosas. Puede ser un proyecto interesante en un futuro, pero en estos momentos no es más que una semilla que puede germinar. Por tanto, pensé que ya que sólo sería una pequeña aportación a la Academia que fuera una gran aportación para mí misma. El acercamiento al feminismo me ha servido a nivel personal para crecer, para ver y luchar contra desigualdades de las que no era consciente en mi día a día. Quería utilizar también esta tesina para seguir creciendo como persona, para normalizar un poco más la sexualidad y aportar mi pequeña ayuda a desenmascarar un sistema patriarcal normalizado y asentado en algo que debería ser tan nuestro y placentero como la sexualidad.

Mi acercamiento al Hentai ha sido más bien a una edad adulta. El porno, sobre todo esas películas de EEUU, era parte de mi imaginario, pero no así el Hentai. La primera vez que lo vi, pasada muy de largo mi adolescencia, me pareció un porno mucho menos agresivo. En cambio, no me ocurrió así con la primera vez que vi una película pornográfica, quizá por la edad, siendo más joven, o quizá por la forma en que era representada. Fue eso lo que me llevó a plantearme que quizá no era la única que tenía la misma sensación, que veía el Hentai no como un porno estridente y masculinizado. Explicaré en el capítulo cero más ampliamente mi acercamiento al Hentai.

Me interesa el estudio del Hentai en cuanto que puede ser un tipo de porno para cualquier gusto, independiente de la orientación sexual o género. El hecho de ser dibujos hace que se puedan plasmar todo tipo de fantasías sexuales. Por ello me decidí con esta tesis de máster a analizar un poco más allá de lo que he visto como usuaria.

Por otra parte, querría aclarar que no pretendo hacer una crítica a la cultura japonesa, que sólo conozco a nivel teórico sin haber tenido una inmersión en el país ni contacto directo a través de gente cercana. Como ya he comentado, en mi investigación pretendo hacer hincapié en la sexualidad y utilizar como motor de ésta el Hentai. Retomando el hilo de la cultura japonesa, en realidad considero que tampoco se puede hablar de la cultura japonesa como un total. Las fronteras no son algo estático, 
por lo que hablar de Japón como un todo no responde a una realidad. Sin embargo, no veo otra forma para referirme a una determinada cultura que cayendo en las generalizaciones. Es por ello que hablaré de la cultura japonesa y española utilizando concepto, sin pretender, con ello, reforzar el concepto de Estado Nación. (MARTÍNEZ: 2009)

Para finalizar este apartado, me parece importante la idea en la que hace hincapié Raquel Osborne:

"Si la sexualidad no responde a nada esencial ni natural sino que se halla histórica, cultural y socialmente construida, y si además la analizamos en un contexto de dominación/subordinación, la consecuencia será que podemos cambiar esas pautas, pero para ello necesitamos, entre otros factores, mucha más investigación y rigor académicos a la hora de tratar esta temática." (OSBORNE: 1995-25).

Esta idea, quizá no expresada en mi mente de forma tan concreta o quizá sí, fue la que me llevó a embarcarme en este proyecto de analizar el Hentai desde una perspectiva feminista. 


\section{Capítulo 0: Donde todo empieza. El por qué de un análisis del Hentai desde una perspectiva feminista.}

Como ya comento en la introducción, la sexualidad a través del Hentai no es una temática típica de investigación, si es que alguna investigación de estudio lo es. Me parece importante el analizar mi situación personal para llegar a la conclusión de por qué he decidido centrarme en esta temática en concreto en relación a este proyecto final de máster. Creo que mi vivencia personal con respecto a la sexualidad ha tenido un proceso de deconstrucción. En una fase muy avanzada de este proceso he tenido un acercamiento con el Hentai, que me ha ayudado a seguir deconstruyendo conceptos e ideas que venían en mi bagaje personal. Me parece sin embargo, que será mejor empezar por el principio de mi vida para así entender el final, el por qué del Hentai. Este primer capítulo será una reflexión personal sobre mi vivencia de la sexualidad de forma etnográfica. He decidido llamarlo capítulo 0 para hacer una diferenciación con el resto de la tesina. Esta parte es el por qué de todo lo posterior, es el comienzo para entender la sexualidad en otros términos y desde otras vivencias, es el punto cero.

Creo que quiénes somos, nuestros gustos, nuestros intereses, en gran medida se deben a las experiencias que hemos tenido. Son nuestras experiencias personales las que nos llevan a ser quiénes somos y cómo somos. La realidad viene a partir de la propia experiencia. Me parece importante en esta tesina también posicionarme yo con respecto a la vivencia de mi sexualidad.

Como comenta Deborah Cameron:

"Nuestras sexualidades están socialmente y discursivamente construidas entre una serie compleja de posibilidades y experiencias; entre éstas, de todas formas, existen las representaciones del sexo que nuestra cultura provee, los textos que leemos, las películas que vemos, y demás". (CAMERON, 1990: 787)

Estoy de acuerdo con la idea que comenta Cameron. Nuestra sexualidad es un entramado de circunstancias e influencias y en mi caso no iba a ser menos.

Me gustaría puntualizar que de momento no voy a hablar de la evolución de la política sexual del movimiento feminista, sino de la inmersión y normalización de la teoría 
feminista en mí, en mi forma de entender el mundo y vivenciarlo en relación a la sexualidad.

Señalar lo que comenta Cristina Garaizábal:

"Pues aunque esta evolución no haya sido sólo mía sino que ha sido compartida con un extenso grupo de mujeres, el movimiento feminista hoy es tan amplio y diverso que creo que nadie puede alzarse con el patrimonio de las ideas feministas sobre la sexualidad. " (GARAIZABAL, 2009:1)

No existe una unanimidad de opiniones sobre la sexualidad desde el feminismo, si no unas pautas que se pueden compartir o no. En este capítulo no pretendo desentramar las verdades de la sexualidad, cuando ni entre los feminismos muchas veces se ponen de acuerdo, sino contar mi historia de vida desde una perspectiva feminista.

Empezaré explicando mi relación con el sexo a una edad infantil. No tengo ningún recuerdo de infancia asociado al placer, al erotismo o a la excitación. Para mí no es que el sexo fuera pecado, es que no se manifestaba de ninguna forma, no existía. Atendiendo a Michel Foucault:

"Siglo XVIII: Sería el comienzo de una edad de represión, propia de las sociedades llamadas burguesas, y de la que quizá todavía no estaríamos completamente liberados. A partir de ese momento, nombrar el sexo se habría tornado algo más difícil y costoso. Como si para dominarlo en lo real hubiera sido necesario primero reducirlo en el campo del lenguaje, controlar su libre circulación en el discurso, expulsarlo de lo que se dice y apagar las palabras que lo hacen presente con demasiado vigor" (FOUCAULT, 1977:25)

Eso es lo que existía en el entorno que me rodeaba. Un control del lenguaje con respecto a la sexualidad, un apagar las palabras antes de ser pronunciadas. Mi despertar de la sexualidad no se dio hasta una edad adulta. Yo no me toqué hasta pasada mi mayoría de edad, no tuve ningún contacto con mi cuerpo en la infancia. El entorno familiar tampoco potenciaba la sexualidad en ningún sentido. No recuerdo haber tenido la típica conversación de madre- hija sobre los preservativos. En mi familia por tanto no se abordaba la sexualidad de ninguna manera. No era negativa, no era positiva, era inexistente. Sí recuerdo, sin embargo, que de niña mis padres cambiaban el canal de la televisión si había alguna escena erótica. El sexo no era 
nombrado de forma explícita, pero de forma implícita el mensaje que yo recibía era que el sexo era algo a esconder.

Por tanto, durante toda mi infancia mis referentes en relación a la sexualidad eran mínimos o nulos. Recuerdo siempre una anécdota que hace muy patente mi desconocimiento sobre mi cuerpo y sus reacciones. Estaba en plena adolescencia, tendría como quince o dieciséis años. Había quedado con unas amigas y empezamos a contar chistes. Cada vez los chistes tenían más connotaciones sexuales. Recuerdo mi sentimiento de no estar a gusto en lo que habían empezado siendo unas bromas y se iba convirtiendo en una conversación que para mí en ese momento era chirriante e incómoda. Yo por supuesto tampoco es que supiera ningún chiste sobre esa temática, así que todavía me sentía más fuera de lugar. Esa sensación se incrementó aún más cuando una amiga contó un chiste al que todas las demás rieron a carcajadas y yo reí por no desentonar del grupo. Recuerdo que el chiste era éste:

“¿Cómo sabe una pija que está enamorada? Por las mariposas en el estómago. ¿Cómo sabe una guarra que está enamorada? Porque cuando se quita las bragas, si las tira al techo, se quedan pegadas".

No entendía de qué se reían mis amigas. No entendía el referente de estar mojada. No lo había sentido en mi cuerpo ni me lo habían contado. Existía un desconocimiento total. Para mí, mi cuerpo era un ente hostil del que formaba parte. No era un lugar de disfrute, si no de miedos y desconocimientos.

Debido a mi falta de referentes, mis relaciones sexuales fueron totalmente desastrosas. Comencé pasada mi adolescencia. De todas formas, el ser ya adulta no ayudó a mejorar la situación. Al no disfrutar mi cuerpo conmigo misma, no podía disfrutarlo estando en pareja tampoco. No me había masturbado nunca antes de que tuviera relaciones con penetración y no fue hasta mucho tiempo después cuando comencé a masturbarme.

Además de todos los miedos e inseguridades, surgió un problema añadido. No sabía que tenía alergia al látex. Cuando tenía relaciones con preservativo tenía muchísimos picores. No lo comenté con nadie en ese momento. Pensaba que los picores eran una reacción mía ante la situación o que sería algo pasajero. Mi pareja me decía lo mismo, que los picores no eran reales si no una reacción psicológica. Hubo meses de escozores que por supuesto acababan en no penetración y frustración. Tanto para mi pareja como para mí en ese momento el único y último fin era la penetración, y si no lo conseguíamos, venía un gran sentimiento de frustración e impotencia. Intentábamos 
penetración en cada acto sexual, disfrutara yo con ello o no. Finalmente, probé a hormonarme usando el anillo vaginal ${ }^{1}$, una forma de anticonceptivos vía vaginal. Por supuesto, los picores desaparecieron. Mucho tiempo después, al probarme unas bolas chinas de silicona, entendí que mi problema con los preservativos era el látex. Fueron muchos años que por desconocimiento e invisibilización de la sexualidad y la mía en particular no pude solucionar ese problema. Es gracioso cómo me he encontrado en la situación de que algún chico me haya insinuado que soy una mentirosa si no tenemos condones de látex y yo no quiero que haya penetración sin ellos. Es la idea de lo falocéntrico y de relación no completa sin penetración que existe en nuestro imaginario social. (DE BEJAR: 2003)

Mucho tiempo después, hace cosa de un año, me ocurrió una anécdota que creo que es digna de ser contada en esta autoetnografía. Una amiga, que vive en otro país, me escribió un correo electrónico. En él, entre otras cosas, me comentaba que estaba triste. Me decía que se sentía deprimida sin saber bien por qué. Le pregunté el motivo pero estaba reacia a contármelo. Al final, después de insistir con varios mails, me comentó que no estaba bien porque las relaciones sexuales no iban bien con su pareja. Llevaba cinco años con él pero no había penetración porque ella no se encontraba cómoda, le picaba, le escocía. Le dije al momento que era probable que tuviera alergia al látex y que probara condones hipoalergénicos. Me escribió pocos días después para darme las gracias y decirme lo muy agradecida que estaba conmigo por habérselo dicho. Habían probado los condones sin látex y no le había picado ni habían tenido ningún problema con la penetración. Ese día lloré. Lloré por una parte de rabia. De rabia porque ese tabú afecta a nuestra vida, sobre todo si somos mujeres. Pero también lloré de alegría, lloré del sentimiento de orgullo que sentía en ese momento. Por no haber tenido vergüenza a comentar una cosa que podía cambiar su vida, por haber creado ese espacio de intimidad y confianza entre nosotras. El tabú me había afectado a mí en gran medida en su momento. Mucho tiempo después me encontraba que también le afectaba a esta amiga. Sentí una vez más que hasta el momento había vivido lo que describe Foucault en torno al sexo: silencio.

"Funciona como una condena de desaparición, pero también como orden de silencio, afirmación de inexistencia, y por consiguiente, comprobación de que de todo eso no hay nada que decir, ni ver, ni saber." (FOUCAULT, 1977:10)

\footnotetext{
${ }^{1}$ El anillo vaginal, anillo mensual o anillo anticonceptivo es un método anticonceptivo hormonal de duración mensual que consiste en un aro o anillo del material plástico que se coloca en la vagina, y libera hormonas femeninas en dosis bajas y constantes y impiden la ovulación
} 
Como he comentado, al comenzar a tener relaciones sexuales éstas no es que fueran muy placenteras. Comenté mi situación por encima con amigas, sin explicar mucho. Una de ellas me recomendó un libro sobre sexualidad, "Tu sexo es tuyo" de Silvia de Bejar (DE BEJAR: 2003). Es gracioso recordar cómo mi amiga en ese momento me comentó que el libro hacía apología del feminismo, pero que quitando eso, estaba bien. La asociación negativa del feminismo se hacía patente. Ahora que trabajo en una librería me alegro cuando alguien compra ese ensayo. Sonrío y pienso que sus ideas sobre la sexualidad van a cambiar al menos un poco.

Volviendo a "Tu sexo es tuyo", este ensayo fue un hito en mi historia personal. Leerlo fue como empezar a entender un poco más. Era la primera vez que me preocupaba por mi sexualidad. Por desgracia, no me preocupaba por mí misma, si no por otra persona, en este caso mi pareja. No estaba preocupada por mí misma y por mi propia sexualidad. Estaba preocupada por cómo podía influir eso en mi chico. Era una carga que yo me imponía.

Comenta Alicia Puleo:

"el mito del amor se ha readaptado desublimándose y convirtiendo la práctica sexual que antes era cínicamente "disculpada" en una nueva exigencia. Del "Patriarcado de Coerción" que prohibía las prácticas sexuales se ha pasado al "Patriarcado de Consentimiento", que impregnado de la ideología del amor prescribe la práctica de la sexualidad como una nueva obligación. Según este nuevo precepto amoroso, las mujeres de verdad para ser completas han de ser deseables y satisfactorias sexualmente. Si a esa exigencia sumamos la responsabilidad de la salud emocional de la pareja, la presión que el mito del amor carga sobre las mujeres es extraordinaria." (JIMENO: 2009)

Para mí el sexo se había convertido en una obligación. Y lo que es más, en una responsabilidad para con mi pareja, porqué él quería tener sexo, tenía que pensar en sus sentimientos y necesidades.

La relación decayó tanto que acabamos rompiendo, entre otras cosas porque sexualmente no disfrutábamos. Fue en ese momento cuando decidí empezar una terapia sexológica. Fue un antes y un después en mi planteamiento de la sexualidad. Recuerdo cómo el primer día el sexólogo, (sí, era hombre) me dijo que cuando llegara 
a casa me viera la vulva con un espejo. Me pareció la mayor estupidez que me habían dicho nunca. Yo sabía cómo era, ¿para qué tenía que mirarla? Pensándolo después me di cuenta que aunque debía saber cómo era, jamás la había mirado. No sabía dibujar su forma ni qué color tenía. Nuestro sexo, nuestra vulva, es desconocida por muchísimas de nosotras. (DODSON: 1989) Esa parte del cuerpo desaparece por completo, como si no existiera. Sólo existe, en todo caso, para depilarse y lavarse. El asistir a terapia cambió totalmente mi percepción del cuerpo. Me dio pautas que tenía que seguir, cómo tocarme, acariciarme y mimarme. Cosas que parecían tan simples de repente me creaban ansiedad. Hasta ese momento nunca había disfrutado de mi cuerpo, nunca me había tocado. No sabía de qué forma tenía mi culo ni cómo era su tacto. Hasta entonces sólo le había prestado atención para ver si estaba más gordo o más delgado. Poco más o menos me pasaba con otras partes erógenas como los pechos.

Mi primer orgasmo lo tuve con 24 años después de seis meses de terapia sexual y ayudada. No lo solucioné con ayuda de una pareja, sino con la ayuda de un amigo con el que tomamos el sexo como un juego más. Para mí el orgasmo no fue esa sensación maravillosa que nos venden de ver estrellas o fuegos artificiales. Tuve tal estrés que lloré después de tenerlo. No era llanto de alegría ni de felicidad, sino de pura ansiedad. Esa ansiedad que venía por dejar mi cuerpo disfrutar, por sentir el deseo, por hacer algo que no debía, que no podía. A partir de ese momento, la relación con mi cuerpo ha cambiado mucho pero todavía recuerdo ese malestar, ese ataque de ansiedad que tuve en ese momento. Entonces, por ese recuerdo, es cuando me digo que hay que deconstruir esa sexualidad natural y normalizada que nos venden y nos creemos.

Un tiempo después de la terapia, empecé el máster de estudios de las mujeres y de género, GEMMA. Entrar al GEMMA me ayudó a afianzar la idea de la sexualidad como una construcción social y cómo esta sexualidad puede ser usada como una herramienta política y reivindicativa.

Volviendo a la adolescencia, como he comentado más arriba, para mí durante esa etapa la sexualidad fue prácticamente inexistente. No existió en mi entorno familiar o social. Tampoco tuve un acercamiento a través del porno. Como comenta Beatriz Preciado, la pornografía puede ser entendida como pedagógica. (PRECIADO, REDES). Se encuentra la misma idea que expone Beatriz Preciado en Erika Lust cuando pregunta: 
“¿El porno es una perversión o puede ayudarnos a aprender cosas sobre nuestra sexualidad?" (LUST, 2009:32)

En mi caso no fue así para nada. Para mí el porno era algo totalmente extraño, algo por lo que no sentía ningún interés o vinculación. Mi imagen mental de la pornografía siempre había sido como la describe Adlys:

"Ellos ven videos y a menudo los ven juntos, compartiendo cervezas, risas y deseo. La pornografía puede ser una forma de unión masculina, pero no está diseñada para crear la misma clase de disfrute para las mujeres. El deseo femenino debe de permanecer escondido y privado". (ADLYS, 1993:60)

Mi imagen mental de una peli porno era la de un grupo de chicos jóvenes en un comedor, quizá en la casa de los padres de uno de ellos, masturbándose y viendo "eso". Ese algo sórdido y obsceno. Algo totalmente separado de mí y de mi círculo social. Ya de adulta he visto alguna película porno e incluso algunas de las que se autodenominan feministas, como "Cinco historias para ellas"2. La verdad, no le veía gracia alguna. Me aburrían más que excitaban.

Aunque no he visto mucho porno, sí que leía novelas románticas en mi adolescencia. Recuerdo que las escondía en un cajón para que mis padres no las vieran. No sabía bien qué le pasaba a mi cuerpo pero sabía que era algo vergonzoso porque escondía lo que me producía esas sensaciones. Los hombres ven porno, las mujeres leen novelas románticas. Las novelas románticas son el equivalente en las mujeres de lo que es el porno en los hombres. Citando de nuevo a Adley:

“El femenino equivalente es probablemente las novelas románticas. Millones de chicas jóvenes y mujeres de todo el mundo tienen fantasías con Arlequín (novela romántica). Pero la fantasía erótica que estos libros se describe es un placer sexual en términos patriarcales. Primeramente, las escenas de amor y sexo siempre acaban cuando está empezando lo bueno. Segundo, el sexo que los hombres ven en Playboy y otros pornos es puro sexo. El sexo que las mujeres ven en Arlequín está siempre intrínsecamente unido al amor. Para los

\footnotetext{
${ }^{2}$ Cinco historias para ellas es una película erótica y pornográfica producida en España en 2007, producida por Lust Films, y dirigida por Erika Lust.
} 
hombres estos dos pueden estar separados, para las mujeres nunca." (ADLYS, 1993:60)

En mi caso me siento totalmente identificada de adolescente con esa definición. Esa idea del sexo unida al romance, al estar enamorada y el "vivieron felices para siempre". Haciendo una comparación con el chiste que me contaron, era sentir esas mariposas en el estómago pero no la excitación consecuente.

Mucho tiempo después encuentro un material que no es la novela romántica, que no es el porno típico, que es algo distinto. Para mí el Hentai fue un gran descubrimiento en este proceso personal. De repente surgía para mí un porno que no lo asociaba con masculinidad y/o obscenidad. El Hentai, en cómic, me lo pasó un amigo hace un par de años. Sí, el mismo con el que tuve mi primer orgasmo. Me pareció algo muy gracioso y nada agresivo. Me recordaba mucho a dibujos que había visto en $\mathrm{mi}$ infancia o adolescencia. Dibujos como Bola de Dragón ${ }^{3}$, Ranma $1 / 2{ }^{4}$ o La familia crece $^{5}$. Aunque estos tres títulos los había visto en formato anime (dibujos animados), la estética era muy parecida a la del Hentai del cómic. Aunque la temática fuera sexual, me era muy familiar y no lo asociaba a malestar o sordidez como podía ser el caso del porno. Me gustaba que fueran dibujos con colores pasteles y de trazos suaves.

Una de las primeras veces que recuerdo haberme masturbado con algún material pornográfico, fue por un Hentai, mi primer Hentai. El primer cómic que leí fue "Bondage fairies", que analizaré más extensamente en el cuarto capítulo. Los dos personajes principales son dos hadas que mantienen una relación homosexual. En este volumen existen relaciones sexuales consentidas y no consentidas, pero en los dos casos entre mujeres/hadas. Me chocaba por una parte que no hubiera varones en la historia. El único rol masculino era secundario y lo constituía un orangután. Aunque había violaciones, eran entre mujeres así que quizá por eso no lo vi como relaciones patriarcales de dominación. Otro pro añadido que encontré en el Hentai es la

\footnotetext{
${ }^{3}$ Del autor japonés Akira Toriyama. En España, la serie cobra importancia a través de su retrasmisión en televisiones autonómicas a partir de 1989. Cuenta la vida de un niño, Son Gokuh, desde que es pequeño hasta que se hace adulto, mezclando la temática de artes marciales con aventuras.

${ }^{4}$ Del autor Rumiko Takashasi, publicado entre 1987 y 1996 en España. Cuenta la historia de Ranma, un chico adolescente que al contacto con el agua fría se convierte en chica. Las aventuras y desventuras de éste con su prometida Akane. La temática mezcla artes marciales y situaciones amorosas.

${ }^{5}$ Del autor Wataru Yoshizumi, en España fue emitido por La 2 en 1998. Trata la historia de amor entre dos adolescentes, Mikie y Yuu y sus temas diarios.
} 
estimulación de mis fantasías sexuales. Descubrí un material cuyo único propósito es la excitación sexual. Pero no sólo eso, ya que esta definición también puede hacer referencia al porno. Descubrí un material cuyo único propósito se dirigía a una excitación particular, la mía.

Me daba cuenta que hasta el momento no había tenido fantasías sexuales y de repente se abrían mil ideas que podía usar en mi cabeza, que me servían para excitarme. Es importante hacer hincapié en el conocimiento del propio cuerpo, pero lo mental también es fundamental para la excitación.

Para mí la sexualidad ha sido una deconstrucción absoluta. Una deconstrucción para volver a construir, para seguir construyendo de forma distinta. Construyendo teniendo en cuenta la parte cultural de la sexualidad. Como refleja Rubin:

"La sexualidad y las prácticas sexuales -el homoerotismo y las sexualidades no normativas - parecen a priori un asunto privado y de poca importancia, que sucede en la intimidad y que están lejos de las políticas públicas. Esta idea aparece junto con otras, como la de que la sexualidad fuese una fuerza natural que existe con anterioridad a la vida social y que da forma a las instituciones; como si fuera algo inmutable, asocial y transhistórico; o la de que el sexo como propiedad de los individuos, que reside en sus psiques y sus hormonas. Estas concepciones erróneas aparecen enraizadas en la cultura occidental, de forma que no se cuestiona la sexualidad, y reaparecen en diferentes momentos históricos con diferentes formas culturales." (RUBIN, 1989:130 en PLATERO: 2004).

Después de mucho leer, documentarme, me he dado cuenta que mi experiencia personal no es más que otra entre tantas vivencias complicadas y difíciles en torno a la sexualidad que tenemos en especial las mujeres. Creía que lo que yo estaba viviendo no era "normal", pensaba que yo había hecho algo mal al vivenciar la sexualidad de esa manear. Pensaba que era la única "bicha rara" a la que le pasaba eso. Incluso tendía a culpabilizarme a mí por ello, como si fuera mi culpa y no del sistema patriarcal en el que me encuentro inmersa. Me pareció importante el hablar desde mi experiencia personal ante todo para saber que no estamos solas en esto, para no culpabilizarme por ello o pensar que existe "la normalidad" en la sexualidad.

Porque ante todo, me parece fundamental reivindicar nuestro placer, nuestra sexualidad y nuestro goce. 
Como dice Itziar Ziga:

"No hay mayor insumisión que la risa y el placer. Nos negamos a ser guerreras de ceño eternamente fruncido y piernas cerradas. (...) Nos oponemos a reprimir nuestro deseo, congelarnos como bestias en permanente alerta. Somos manada furiosa, devenimos perras." 6

6 Vídeo promocional del libro "Devenir Perra" de Itziar Ziga: http://www.youtube.com/ watch?v=boR8SuSOVm8 


\title{
Capítulo I. Debates sobre pornografía y sexualidad desde el feminismo
}

1. Definición de género, sexo, sexualidad.

\author{
«El bebé, ¿es niño o niña?». \\ — «No lo sabemos, todavía no nos lo han dicho». \\ «Sexo: Varón Mujer» «Sexo: Sí (BORNSTEIN, 1994: 46 en TRUJILLO ET AL,
} 2005:21)

A lo largo de este trabajo utilizo conceptos como sexualidad, género y sexo, lo que me parece conveniente en un principio definirlos. Realizar una pequeña contextualización con respecto a estas palabras, ya que son conceptos que utilizaré a lo largo de esta tesina. La utilización de estos términos la considero especialmente necesaria para el capítulo IV donde analizo tres cómics Hentai. En ellos analizaré más ampliamente cómo son abordados temas como la homosexualidad, el travestismo y la identidad de género. Por otra parte, siendo entendido el Hentai como un material pornográfico, realizo en este capítulo un contexto histórico sobre los debates feministas en relación a la pornografía desde los años 70 hasta el momento actual.

Empezaré en primer lugar enmarcando el concepto de género. Como explica Raquel Osborne:

"Entendemos por género el constructo social que convierte a hombres $y$ mujeres en seres sociales frente a su concepción como meras entidades biológicas, seres que por lo demás se hallan encuadrados en unas determinadas relaciones de dominación/subordinación”. (OSBORNE, 1995: 25)

El concepto de género surge con Simone De Beauvoir en el siglo XIX. Es conocida su obra "El segundo sexo" escrita en 1949, en el cual se hace famosa la frase "no se nace mujer, se llega a serlo". Lo que pretendía De Beauvoir con esta afirmación es diferenciar entre la parte biológica y la parte cultural, las diferencias culturales y sociales entre mujeres y hombres. El surgimiento de un concepto como "género" supone una revolución en cuanto al determinismo que venía asociado a las mujeres, 
asignadas al ámbito privado por definición. Retomando esta idea, los movimientos feministas de la primera ola, en los años 70 del pasado siglo, revindican la igualdad jurídica pero también la división entre ámbito privado y público y la opción de las mujeres a poder entrar en este último.

Desde el movimiento queer, se da un paso más en relación a estos conceptos. El texto de Judith Butler de 1990 "El género en disputa", se convierte en otro hito del feminismo. La idea revolucionaria de que no existe una línea clara entre sexo masculino y femenino, una categorización binaria, si no que la línea es mucho más difusa. Aspecto también desarrollado por diferentes autoras.

"La verdad del sexo, de los cuerpos sexuados, resulta ser mucho más inestable de lo que se nos antoja a simple vista. El género y aún el sexo y la sexualidad como verdades políticas tienen una emergencia reciente y su mantenimiento requiere de un control férreo. De ahí la persecución cotidiana e institucionalizada de las ambigüedades y fluideces de sexos, géneros y deseos. Así pues nos resistimos y por eso también infundimos un diferente tipo de terror: la violencia, el vértigo, incluso la náusea, la desorientación provocada por la persona rarita que no encaja en las categorías cognitivas del dualismo sexual. Pero la revulsión tiene una peculiar conexión con el deseo: el vértigo se provoca por la atracción de caer al vacío, la otra rarita provoca pánico porque confronta a las personas con la seguridad de sus cuerpos normalizados, pero también por el peligro de una atracción que cuestiona esos límites." (TRUJILLO ET AL, 2005:22)

La intersexualidad es otro de los temas candentes en el feminismo. También este concepto hace poner en duda los referentes de sexo femenino y masculino. Intersexuales son aquellas personas que no nacen con genitales exclusivamente que sean asignados por la ciencia como masculinos o femeninos Las respuestas desde la sociedad no es la aceptación si no la medicalización y tratamientos médicos y quirúrgicos. Como analiza Beatriz Preciado, desde la sociedad se intenta el categorizar a este tipo de personas dentro de cuerpos masculinos y femeninos ya sea a través de medicación o cirugía. Se pretende una corrección de los cuerpos que no entren dentro de la categoría femenina y masculina.

"Con las nuevas tecnologías médicas y jurídicas de Money, los niños "intersexuales", operados al nacer o tratados durante la pubertad, se convierten 
en minorías construidas como "anormales" en beneficio de la regulación normativa del cuerpo de la masa straight (heterocentrada). Esta multiplicidad de los anormales es la potencia que el Imperio Sexual intenta regular, controlar, normalizar" (PRECIADO: 2003).

También la transexualidad o transgénero hace desestabilizar las identidades binarias. En referencia a transexual, transgénero, son aquellas personas que no sienten que su cuerpo corresponda con la asignación de género dada. Según algunos autores y autoras, existen diferencias entre la palabra transexual y transgénero.

"Transexual: Aquellas personas que entienden que la no correspondencia entre sexo y género requiere modificar su cuerpo mediante hormonación y cirugía. Esto supone que podíamos denominar transexual a una persona que considera necesario transformar su cuerpo aunque no lo haya hecho (por razones económicas, de salud, por ser menor de edad...)"

"Transgénero: sería aquella persona que cuestiona la necesidad de escoger entre los roles masculino y femenino y que no considera necesario establecer una correspondencia entre sexo y género mediante la transformación corporal. Lo definitorio de esta categoría es la concepción de la transexualidad, al margen de si la persona ha efectuado o no alguna transformación a nivel hormonal o quirúrgico." (MISSÉ, COLL-PLANAS, 2010: 22)

Esto lleva a una concepción del género más amplia que la de hombre y mujer. Muchas personas no se sienten dentro de estas categorías a las que hay que constreñirse. La lucha de muchos movimientos trans a día de hoy se basa en despatologizar la transexualidad dentro de la OMS (Organización Mundial de la Salud), para que sea entendido no como una enfermedad si no como una representación más del género. (ÍBIDEM, 2010)

En relación a los conceptos anteriormente nombrados, se encuentra el de sexualidad. Hago mucha referencia a esta idea en mi autoetnografía, en el capítulo O, por lo cual quiero hacer una pequeña nota con respecto a este concepto. Aunque ya lo he comentado anteriormente, la sexualidad es una construcción social dependiente de muchos factores. 
Si nos basamos en la Real Academia de la lengua, el significado que se le da es bastante pobre. Así, si nos atañéramos a lo que dice este diccionario, se haría referencia a:

1. f. Conjunto de condiciones anatómicas y fisiológicas que caracterizan a cada sexo. 2. f. Apetito sexual, propensión al placer carnal.

Sin embargo, como comenta Jennifer Robertson la sexualidad es un entramado más complejo:

"Sexualidad" puede solaparse con sexo y género pero se refiere a un ámbito del deseo y placer erótico mucho más complejo y variado que la construcción hegemónica de la reproducción" (ROBERTSON, 1998: 17)

Asimismo, existe en el imaginario social una idea de un esencialismo sexual. El sexo entendido como "natural" en vez de un constructo social. Como analizaré más adelante en el capítulo cuarto, existe una construcción social en referencia a las prácticas sexuales, tabúes y patologías que disienten de lo aceptado socialmente como sexualidad.

\section{Debates antiporno, proporno}

Este punto se centra en cómo el feminismo se ha posicionado entorno al material pornográfico, dentro de los que se encuentra el Hentai. El debate desde el feminismo sobre la pornografía ha sido controvertido. Al igual que con otras temáticas como puede ser la prostitución, no hay unanimidad en su posicionamientos desde la teoría feminista.

Los debates sobre la pornografía cobraron mucha importancia en los años 80 sobretodo en EEUU, después de la segunda ola del feminismo y la revolución sexual de los años 70. A diferencia de la primera ola donde los debates se centraban en discriminaciones más patentes como el derecho al voto, en la segunda ola se hablan de desigualdades y diferencias menos visibles. En este contexto surge la cruzada 
contra la pornografía desde el movimiento antiporno. Éste, junto al proporno, son las dos voces principales sobre la pornografía desde el feminismo.

En referencia al movimiento antiporno, hay muchas autoras representativas, sin embargo las máximas representantes en EEUU son Andrea Dworkin y Catherine Mackinnon. Desde el feminismo antiporno se habla principalmente de la subordinación de las mujeres en todos los ámbitos. Uno de los ámbitos donde existe una mayor subordinación es el referente a la pornografía. El porno por tanto es visto como otra forma de desigualdad entre mujeres y hombres y una pornografía entendida como identidad masculina. El argumento principal de las antiporn se basa en que las mujeres están consideradas como objetos sexuales en la pornografía. (DOLAN, 1987)

Como resume Cristina Garaizábal:

"Se conforman como corriente en los años 80 en EEUU. Sus autoras más significativas son: Andrea Dworkin, Mary Daly, Susan Griffin, Katheleen Barry, Adrianne Rich, Alice Schwartzer... El "sadismo cultural" es el conjunto de prácticas sociales que favorecen y propugnan la violencia sexual. Condenan la pornografía y la prostitución por ser manifestaciones prácticas del sadismo cultural." (GARAIZABAL, 2009:5)

Contra esta pornografía, la corriente antiporno propondrá medidas jurídicas. Esta corriente revindica que la pornografía es una forma de violencia hacia las mujeres que puede ser combatida a través de medidas legislativas, censurando ciertas materiales y restringiendo su uso. Desde este movimiento se entiende el sexo como algo sucio y negativo que es exclusivamente cosa de varones. (FRAIMAN, 1995)

Otro de sus argumentos es el que la pornografía normaliza agresiones hacia las mujeres que después serán llevadas a la práctica por los hombres. Se insensibiliza con las imágenes pornográficas hacia una violencia contras las mujeres. Ello potenciará este tipo de comportamientos por varones.

El movimiento antiporno y discursos tradiciones en Estados Unidos compartieron algunos puntos de vista como la legislación de la sexualidad y la prohibición de ciertos materiales pornográficos. Aunque los argumentos de estas feministas son totalmente distintos de los sectores conservadores, ya que desde éste último se habla de una ruptura de la familia nuclear y de las tradiciones, sí había un apoyo común frente la lucha por la censura de la pornografía. 
Las feministas pro-sex surgen como contestación al movimiento antiporno. Uno de los argumentos de este movimiento es que el porno ofrece una variedad de libertad sexual y de expresión que de otra forma no sería posible. Las feministas proporno hablan de una doble dimensión con respecto a la pornografía. Por un lado, es una perpetuación del sistema patriarcal y por otro la pornografía puede ser entendida como una forma de liberación y empoderamiento. Asimismo, el movimiento proporno defiende que disfrutar de la pornografía es una forma de resistencia a una cultura que no permite placer sexual. La pornografía es esgrimida como una herramienta de liberación sexual en cuanto a un sexo no privado y no reproductivo. (PHILIPSON, 1984)

Por otra parte, las feministas proporno replican que la argumentación del movimiento antiporno puede llevar a la censura de derechos por los que se han luchado desde el feminismo como manuales de educación sexual, representaciones del lesbianismo y de sexualidades no normativas. Como se refleja en las palabras de Raquel Osborne, los argumentos del movimiento antiporno pueden llevar a una negación de la sexualidad femenina:

"Judith Walkowitz ha demostrado que, en su intento de defender a las prostitutas y de proteger a las mujeres en general de la agresión sexual masculina, las feministas británicas de fines del siglo pasado y principios del presente fracasaron estrepitosamente, principalmente por dos razones. La primera, porque en su ataque contra la dominación masculina y "el vicio" masculinos no revindicaron una activa sexualidad femenina. Las mujeres fueron definidas como criaturas morales, espirituales, que debían de ser defendidas de los malvados y "carnales" hombres." (OSBORNE, 1989: 91)

Por tanto, las feministas proporno defienden que el poder, la sexualidad y el deseo han restringido históricamente las habilidades de las mujeres para expresar su sexualidad en la cultura. Pero poder, sexualidad y deseo pueden ser recuperados del dominio estrictamente masculino y ser asumidos con diferentes significados en contextos sexuales y de género distintos. (DOLAN, 1987)

Desde el movimiento proporno se alega que el planteamiento antiporno realiza una crítica demasiado sesgada de lo que es el material pornográfico. Aunque las proporno sí que admiten que puede tener elementos sexistas, por otro lado, este material hacer ver el sexo como un fin de placer en sí mismo y no sólo con intención procreativa. Por otra parte, se defiende el papel de las actrices de este tipo de cine donde no se las victimiza si no que se convierten en mujeres sexualmente activas, que disfrutan con el 
placer y el sexo. Asimismo, otro de los argumentos es el del porno entendido bajo un nuevo prisma. Entendido como un material cuyo objetivo es la excitación sexual y la masturbación en solitario. (OSBORNE, 1989)

\subsection{Contexto español}

El caso de España es distinto al que pudo darse en EEUU e Inglaterra debido a su contexto histórico. En España desde 1939 a 1975 existió un régimen político dictatorial bajo el mando de Francisco Franco. El franquismo paralizó por completo las expectativas feministas. Aunque durante la II República entre 1931 a 1936 sí que hubo muchos avances en cuanto a revindicaciones feministas, como el caso del movimiento anarquista Mujeres Libres, después de la Guerra Civil y la posterior dictadura, se paralizó cualquier tipo de revindicación. Con el franquismo se volvió a la idea de familiar nuclear, el sexo con un sentido procreativo y el papel de la mujer como madre y esposa. Durante el periodo franquista hubo un aislamiento con respecto al exterior, por lo que en España la pornografía no invadió la cultura popular. En EEUU la pornografía se convierte a finales de los setenta principios de los ochenta en un fenómeno de masas. Este hecho es el que lleva en gran medida a los debates consecuentes descritos anteriormente. Debido a este contexto histórico los debates en relación a la pornografía en España no se dieron hasta mucho más adelante. No surgieron hasta los años ochenta aunque no tuvieron la envergadura de los de EEUU. En 1975 se producen la I Jornadas Nacionales para la Liberación de la Mujer, todavía en la clandestinidad. Sin embargo, los debates que allí se dieron no se centran tanto en la pornografía si no en temas como el aborto. (LAFUENTE, 2003)

“En España, las cosas sucederían de manera distinta. Dado que sólo hacia finales de la década del setenta comienza a entrar la pornografía en los círculos de proyección ibéricos, el asunto tardaría en ser tematizado por las feministas locales. De hecho, las voces aparecerían en un orden inverso al de Estados Unidos: allí fueron las antipornógrafas las primeras en sentar su posición pública, frente a la cual reaccionarían las feministas pro-sex, mientras que a España llegaría el debate ya fermentado y serían las opiniones pro-sex las primeras en manifestarse, haciendo eco del debate norteamericano, encontrándose posteriormente con la oposición abolicionista." (PRADA, 2009:76) 
Se puede ver también esta evolución con respecto al porno en España en relación al mundo cinematográfico. Durante los años 70 no existen escenas de desnudos en ninguna película española. Durante la etapa franquista existía una censura muy grande en relación al sexo. No fue hasta la transición de finales de los setenta principios de los ochenta que esta censura comenzó a ser menos estricta. Es en 1983 cuando surge el primer cine orientado a material pornográfico en España. A partir de ese momento el porno ha crecido de forma exponencial, aunque hay que matizar que se ha centrado principalmente en un porno heterosexual. (NEUSCHAEFER, 1994)

\section{Post Porno}

El postporno surge a principios del siglo XXI, dejando atrás los posicionamientos pro y antipornografía. El término viene dado por Annie Sprinkle, actriz porno estadounidense. Aunque ella es considerada como precursora de este movimiento, existen también otros nombres conocidos asociados a él. Éste puede ser el caso de la francesa Virginie Despentes en el cine y la literatura o la española Beatriz Preciado considerada como una teórica especialista en ello. Lo que se pretende con este movimiento es la representación de sexualidades alternativas o disidentes. Se busca con este tipo de porno el hacer al mismo tiempo una reivindicación política y social.

"Nosotras no podemos clasificar nuestra sexualidad dentro de ninguna de estas etiquetas, y como nosotras más y más gente, que ni quiere, ni puede". (LLOPIS, BAÑON, s.f.)

El postporno se concibe por una parte como otra forma de hacer pornografía, pero por otra también de consumirla. Va más allá de la idea de admitir que las mujeres son consumidoras de porno tradicional. Se busca el realizar una deconstrucción del porno para convertirlo en perfomance y reivindicación, de realizar representaciones alternativas.

Desde este nuevo movimiento se tratan temáticas como transgénero y transfeminismo, buscando lugares de encuentro como charlas y talleres. Hablar de un concepto más amplio que "mujer" y romper con los estereotipos de género, revindicando su ambigüedad. 
"El post-porno, o porno experimental o alternativo se impone poco a poco como un espacio para la subversión de las categorías de género y la redefinición de las sexualidades como algo plural, infinitamente rico. Un espacio de lenguaje y de poder con el que construir discursos altamente radicales sobre todos los y las que quedan fuera del porno tal y como lo conocemos". (MUGALARI, 2008)

Como ya he comentado el post porno tiene sus comienzos principalmente de la mano de Annie Sprinkle a comienzos del siglo XXI en EEUU.

Annie Sprinkle nació en Filadelfia y en estos momentos se encuentra en la cincuentena. Comenzó su carrera pornográfica en los años 70 , realizando subgéneros de todo tipo. Después de dedicarse a actriz porno, pasó a ser una activista en temas relacionados con pornografía. Entre sus actividades se encuentran las de escribir libros, dar conferencias en universidades y espacios culturales y perfomances artísticas. En sus talleres se dedica a explicar a las mujeres cómo tener un orgasmo entre otras cosas. Sus perfomances son una reivindicación del sexo como placer, llegando a masturbarse en mitad de una de sus charlas o a tener relaciones sexuales con su pareja, Beth Stevens, o a repartir diplomas a las asistentes agradeciendo su asistencia con títulos como "reconocimiento por los servicios sexuales prestados a la comunidad". (ZIGA, 2009)

"Sprinkle decide pasar al otro lado. A partir de ahí arranca una obra original e inclasificable en la que utiliza todos los soportes que caen entre sus manos (performance, vídeo, instalación, escritura) para explorar el sexo en todo su potencial: artístico y espiritual pero también profundamente político y desde luego feminista. En 1982 Sprinkle se dirige a sí misma en "Deep Inside Annie Sprinkle", una obra experimental que introduce al espectador en un viaje de deconstrucción del fetiche y arroja una mirada nueva -revolucionaria- sobre el concepto de estrella del porno. En ella una Sprinkle de 26 años mantiene relaciones sexuales con diferentes hombres en un cine $X$ en el que se proyecta uno de sus films, mientras otra Sprinkle de 40 años habla directamente a la cámara sobre su vida sexual y personal.” (PTQK, 2012) 
Muchas activistas del postporno español toman como referente a Sprinkle. Como comenta Itizar Ziga, Annie Sprinkle es "nuestra Mamma Posporno, nuestra Perra Alfa". (ZIGA, 2009: 159)

\subsection{Postporno en España}

En España, existen varios referentes en postporno. Algunas de las cuales son María LLopis, Itziar Ziga o Diana J. Torres.

Comenzaré nombrando la activista feminista María Llopis. Llopis, gestiona junto a Águeda Bañón un blog titulado girls who like porn ${ }^{7}$. Se puede acceder a esta web en el cual sus creaciones son bajo una licencia Creative Commons. Al igual que en el caso de Annie Sprinkle, sus actividades son de distinto índole. Entre ellas se encuentran grabación de vídeos, realización de talleres de pornografía y trasmisión de un feminismo con un enfoque didáctico. (RUBIO, 2007)

Parafraseando a Llopis sobre este movimiento:

"Por muy liberales que seamos, por mucho que follemos, ésa no es la solución. Necesitamos otra manera de entender el sexo que supere el mito, el tabú, el tedio, la heteronormalidad, el euro rosa y la genitalización, no sólo de nuestras relaciones sexuales sino también de nuestras identidades." (LLOPIS, BAÑON, s.f.)

María Llopis, además de gestionar el blog junto a Águeda Bañón, ha publicado recientemente un libro titulado "El postporno era eso" en la editorial Melusina en el cual narra sus experiencias personales (LLOPIS, 2010). Hacer mención especial a la editorial Melusina, un referente en relación a la biliografía postporno. En esta editorial se pueden encontrar además de textos de María Llopis, de Itziar Ziga, en la misma línea que ésta última. Ziga revindica el revisar los conceptos de transexualidad y prostitución.

Por otra parte, nombrar que en la misma editorial está editado "Porno para mujeres" de Érika Lust. Hacer una breve alusión a su autora. Lust es contemporánea a las autoras postporno aunque no se enmarca dentro de este movimiento. Ella revindica un porno de mujeres y para mujeres. Su filosofía se basa en una revisión del porno teniendo en cuenta los gustos de las mujeres, sin buscar formas alternativas de plasmar el género.

\footnotetext{
${ }^{7}$ http://girlswholikeporno.com/
} 
Como comenta Llopis, el movimiento postporno no se identifica con la definición de porno para mujeres:

"La que habla de un porno para mujeres: "Esta etiqueta suele identificarse con los valores que son supuestamente femeninos: dulzura, cariño, música melosa, suavidad". "Creemos que es un error identificar dulzura con feminidad y consecuentemente con mujer. Es esa categoría lo que resulta un insulto. ¿Por qué como mujer tiene que gustarme lo dulce?". (RUBIO: 2007)

Retomando el postporno, otra de los referentes españoles en relación a este movimiento transgresor es Diana J. Torres. Ésta, al igual que María Llopis, publica un blog donde sube vídeos y comentarios. Citando a Torres de su web "pornoterrorismo":

"A través del terror que puede causar un cuerpo no normativo, un acto sexual no normativo o una conducta sexual "depravada" en una sociedad mayoritariamente sujeta estrictamente a las normas, pretendo originar también una reacción en aquellxs que nos censuran, que nos tienen por enfermxs, por delincuentes, por hijxs del mal' (TORRES, s.f)"

\footnotetext{
${ }^{8} \mathrm{http}: / /$ pornoterrorismo.com/
} 


\section{Capítulo II. Manga, Anime}

\section{Qué es el Manga-Anime}

Después de una contextualización del feminismo dentro del porno para un posterior análisis del material pornográfico Hentai, este capítulo lo centraré en el Manga y el Anime, ya que el Hentai o eromananga, es una subdivisión dentro de estas dos expresiones artísticas. Paso a explicar los conceptos de manga y anime, además de realizar una revisión del estos materiales en el contexto japonés y español. También analizo los tipos de manga- anime, entre los que se encuentra el ya citado Hentai. Para finalizar, detallo cómo se representa la división de género en el manga- anime para entender más adelante su contexto de este material erótico.

Japón ha sido tradicionalmente conocido por el "sushi", comida típica japonesa o los samuráis, antiguos guerreros del Japón. De un tiempo a esta parte, el país nipón ha comenzado a ser asociado también por sus comics manga y sus películas anime. Estos constituyen uno de sus productos de exportación al extranjero.

En Japón existen distintos nombres para "el fenómeno manga", haciendo una distinción entre dibujos animados o en papel. Habría por tanto que diferenciar entre manga y anime. Manga se trata de los dibujos en comics, mientras que el anime es dibujo de animación. Sin embargo, fuera del contexto japonés y de ámbitos de culto internacionales de esta expresión artística, el término manga se utiliza para definir cualquier tipo de dibujo de una estética japonesa, ya sean dibujos animados o en formato cómic. Las diferencias entre manga y anime no son muy relevantes, a excepción de la nombrada anteriormente. Asimismo, las temáticas que se tratan tanto en manga como en anime son muy parecidas entre sí. (GRAVETT: 2004).

El significado del término "manga" puede dar una idea de lo que abarca este término. La palabra se divide en dos caracteres. El primero, man, significa vago o difuso. El segundo carácter, ga, significa imagen. Por lo tanto, la definición de manga en japonés significaría imágenes borrosas o difusas. Esto hace referencia a los trazos de los dibujos, los cuales son finos y a veces vagos. Otra definición más simplificada de la palabra "manga" sería cómic japonés. Un cómic con temáticas muy distintas y orientado a públicos muy diferentes entre sí. (PEREZ: 2009) Por otro lado, la palabra "anime" proviene de la influencia inglesa utilizada para ese tipo de dibujos. Anime proviene de una abreviación del término inglés "animation". (NAPIER: 2000) 
Como he dicho anteriormente, fuera del contexto nipón no existe una idea clara en el imaginario social sobre lo que significan en su totalidad el manga y anime. Tanto el manga como el anime son muchas veces entendidos como dibujos infantiles en los contextos fuera del Japón, no pudiendo estar esta idea más alejada de la realidad.

Describir el manga- anime como dibujos para un público infantil no haría honor a lo que realmente significa. No se trata de una versión nipona de un Walt Disney. Sus historias y finales muchas veces no se basan en lo políticamente correcto ni tienen un final feliz. Sus temáticas son mucho más oscuras y mucho menos aniñadas. Otra diferencia que se puede encontrar con el ya nombrado Walt Disney es el referente a la sexualidad. Los mangas y anime pueden contener muchas escenas de sexo implícito o explícito. Esto dependerá del subgénero que sea y el público al que vaya dirigido. Estos dibujos no están sólo enfocados a un público infantil como se podría esperar según su estética sino que esta forma artística abarca un público muy distinto entre sí debido a su gran número de subgéneros. Por nombrar algunos, existen manga- anime con contenidos tan dispares como la ciencia- ficción, el erótico o de aventuras.

En Japón tanto el anime como el manga están presentes en la cultura de masas. Una de las razones de la normalización de este fenómeno se puede encontrar en las cifras de publicaciones. Un tercio de las publicaciones son cómics manga. Además, esta expresión artística cuenta con gran aceptación social y es comprada por un gran abanico de población. Incluso los dibujantes se han convertido en personajes públicos que cuentan con gran admiración por parte de sus seguidores. Este fenómeno también se ha convertido en un negocio lucrativo a nivel de comercialización. Los personajes más famosos del manga- anime han sido utilizados como protagonistas de videojuegos, figuras y todo tipo de productos inspirados en los mismos. (BERNDT: 1996). El número de ventas y la fama de los y las dibujantes hacen ver la importancia y la aceptación social con la que cuenta en el país nipón. Aunque en España no se llegue a ese nivel de aceptación, sí que se da entre grupos urbanos específicos fans de este tipo de cómics y películas.

\section{Historia del Manga}

El manga y el anime han sido utilizados en el Japón durante siglos. El surgimiento del Manga tiene varias versiones. Una de estas versiones aboga porque sus primeras apariciones fueron alrededor del siglo VII, cuando aparecen las primeras formas de expresión japonesa de influenciadas por China. (WONG: 2006) 
Existen también otras hipótesis con respecto al surgimiento de esta expresión artística. Otra de las variables posibles es la referente a su surgimiento por influencia de EEUU. El cómic siempre ha tenido mucha fuerza en EEUU y se baraja la posibilidad de que esta influencia se traspasara al contexto nipón e hiciera despegar el manga y anime. Como también explica Wong (ÍBIDEM: 2006):

"El ahora usado término para cómics y dibujos, manga, comenzó a ser popular alrededor de mitad de 1700, con el artista impresor Katusushika Housai's (1780-1849). La influencia de Occidente en el manga aparece ya cuando Japón abrió sus puertas a Occidente en el periodo Meiji (1868-1912) cuando la primera revista con estilo occidental- Japan Punch- fue publicada en Yokohama desde 1862 hasta 1887 por un artista británico, Charles Wirgman.”

Las dos hipótesis no tienen por qué ser contradictorias, ya que pueden haberse llevado a cabo las dos en cierto punto. Una cultura no es un ente inmóvil que no reciba influencias externas, por lo tanto el manga pudo desarrollarse en Japón desde la antigüedad, al mismo que tiempo recibir influencias desde EEUU que lo hicieron evolucionar en la etapa contemporánea de una determinada manera.

Volviendo a la historia del manga, su evolución como tal puede ser entendida como contemporánea. Aun así, históricamente en la cultura japonesa siempre han existido en gran medida las imágenes gráficas, entendidas como historietas. Por tanto, estas historietas pueden ser entendidas como un antecedente del manga actual. Los primeros tipos de historietas de las que se tiene constancia comienzan a partir del siglo VI y VII. Estas historias están dibujadas en pergaminos donde se puede encontrar una unión entre imágenes y texto. En un principio este tipo de pergamino es traído desde India y China. Es a partir del siglo XII cuando también se empiezan a reproducir en Japón. Estos pergaminos aparecen en blanco y negro y están realizados principalmente por monjes japoneses. En sus comienzos son imágenes religiosas, pero más tarde se usan para plasmar la vida diaria. La finalidad era reproducir las costumbres del momento en relación a la casa y a las normas sociales. Al igual que otros materiales, como pueden ser las bibliotecas de fortunas particulares hasta el siglo $\mathrm{XX}$, este tipo de pergaminos estaban al alcance de una minoría cultural y económica como era la aristocrática y religiosa. Una cultura sólo accesible para una minoría. (MADRID, MARTINEZ, 2010: 22) En lo que se refiere al Hentai, no es ahí donde tiene sus comienzos, sino en una etapa más contemporánea. 
A partir del siglo XVIII aparecen otras formas de impresión, los otsue y tobae. Los primeros son imágenes anónimas de la ciudad de Otsu y los segundos imágenes satíricas con anotaciones con texto que se publicaban en Osaka. Se imprimen en planchas de madera y es cuando estos papiros tendrán una mayor difusión. A partir de esta nueva difusión también cambiarán las temáticas de las viñetas. En este nuevo tipo de imágenes se representarán escenas de la época, con temáticas basadas en burdeles y teatros entre otros. Aunque comiencen a aparecer plasmados este tipo de lugares, no hay constancia de que existieran también imágenes de relaciones sexuales. Es con este nuevo tipo de impresiones, cuando aparece por primera vez la palabra manga. La primera constancia que se tiene de su uso es en 1815 cuando el autor Katsushika Hokusai utiliza el término "manga" para sus obras impresas. La palabra ánime no surgirá hasta más adelante cuando la televisión sea un fenómeno de masas. (ÍBIDEM, 2010: 23).

Aunque a partir del siglo XIX ya se empieza a nombrar manga, la cultura del manga como tal tiene sus orígenes en el comienzo del siglo XX. Su gran cambio se produce después de la Segunda Guerra Mundial. Antes de la guerra estaba principalmente orientado a un público infantil. Es a partir de la Segunda Guerra Mundial cuando se produce su gran despegue, orientando su venta a un público adulto también. Sin embargo, es en los años 70 cuando el manga crece exponencialmente en importancia en Japón. A partir de este momento su difusión pasa a ser para todo tipo de público. Uno de los motivos de esta expansión es que los niños y niñas que consumían manga en su infancia han crecido y siguen consumiendo este producto. El mercado se expande a un tipo de población más adulta, aunque se sigue manteniendo un público infantil. Es a partir de principios de los 90 cuando Japón comienza a exportar producción de manga y anime. Su primera aparición fuera del contexto nipón se da en EEUU, para dar el salto posteriormente a Europa, específicamente a Europa occidental. (PAPALINI: 2006)

El problema al que se enfrenta en el siglo XXI el Manga Anime es la aparición de internet, habiendo dado paso a un menor consumo en papel y su menor compra. Por otra parte, se facilita el acceso a usuarios fuera de la cultura japonesa que antes no podrían tener acceso más que en librerías especializadas. Como ocurre también en España en el contexto cinematográfico y musical, se crea el debate sobre la utilización de los contenidos en internet y el rendimiento de ellos a nivel económico. 


\section{Contexto cultural del Manga en Japón.}

Anteriormente he citado la gran cantidad de mangas que son publicados y comprados en Japón. Una de las razones del gran consumo de este material es la facilidad con la que se puede transportar. Japón es un país superpoblado y con problemas de alojamiento lo que hace que los japoneses recorran largas distancias desde sus hogares hasta sus puestos de trabajo. Las empresas residen en el centro de Tokyo o grandes ciudades, y las personas se trasladan desde sus casas al centro. El problema estriba en que son trayectos muy largos. Los japoneses pasan una media de tres horas en transporte público para ir a sus respectivos trabajos Esto hace que los mangas sean una opción perfecta para pasar el tiempo en el metro en los trayectos de ida y vuelta. Sirve como una manera de relajación y "olvidarse del mundo". Otro de las razones por la cual se consume manga es la facilidad de compra que existe en Japón. Este tipo de cómic es accesible en muchos establecimientos. Su precio además ronda los 3 euros lo que es un precio asequible para ser comprado, a diferencia de una novela, donde el precio es mucho mayor. Al ser tan baratos, pueden ser comprados para un trayecto desde casa al trabajo y después ser tirados a la basura después de haber sido utilizados. Su uso es muy específico de entretenimiento y temporal. (ALLISON, 2000: 58)

\subsection{Manga-Anime en el contexto español.}

A diferencia de Japón, donde el manga pertenece a una cultura de masas, en España tanto el anime como el manga pertenecen a contextos específicos dentro de una subcultura. Habría de todas maneras que matizar esta afirmación, existiendo casos específicos que sí constan en el imaginario social colectivo. Éste puede ser el caso de la serie "Dragon Ball" o "Bola de Dragón", un fenómeno televisivo de los años 90 que acerca el anime a la población española.

Se puede hablar por tanto de un antes y un después con la emisión esta serie en España, la cual dio a conocer el anime en la cultura española. Bola de dragón, o "Doragon Bōruo" en su título original, es una creación del autor Akira Toriyama, publicado inicialmente en Japón a través de revista manga Shōnen Jump entre 1984 y 1995. El manga fue adaptado al anime por el estudio de animación japonesa Toei Animation. El anime, a diferencia del manga, se divide en dos series. Los primeros 194 capítulos del manga fueron adaptados a la pequeña pantalla usando el mismo nombre con una duración de media hora cada episodio y se emitieron en Japón desde 1986 a 
1989. A partir del capítulo 195 del manga, su adaptación al anime fue llamada "Dragon Ball Z" o "Bola de Dragon Z". Estos capítulos fueron adaptados en 291 episodios de 20 minutos emitidos desde 1989 hasta 1996.

En el caso de España, la serie cobra importancia a través de su retransmisión en televisiones autonómicas a partir de 1989. En 1997 se emite también a nivel estatal a través de la cadena privada Antena 3. El formato cómic no llegó a España hasta mucho después de la primera emisión del anime. Bola de Dragón fue publicada por primera vez en castellano en 1995 por la editorial Planeta DeAgostini. La publicación tuvo lugar entre 1995 y 1998, aunque continúan habiendo reediciones.

"Bola de dragón" está considerado dentro del manga en la categoría de shonen, dirigido a un público infantil- juvenil masculino. En España fue visto tanto por niños como niñas y adolescentes de los dos sexos, siendo parte del imaginario social incluso hoy en día. (RAMIREZ: 2005).

\section{Tipos de Manga-Anime}

Tanto el manga como el anime cuentan con los mismos subgéneros. El manga - anime puede ser dividido de distintas formas. En este caso realizaré una distinción dependiendo del público al que va orientado y el contenido del mismo. Los subgéneros del manga, anime son los siguientes:

Cartoons o comic-strip: de temas políticos y de actualidad. Muchas veces el manga es utilizado con fines adoctrinadores o con propósito de que se conozca más la historia de Japón.

- $\quad$ El manga de gags y del absurdo.

- $\quad$ Story-manga, el manga de aventuras.

- $\quad$ Manga para chicas o shōjo manga.

- $\quad$ Manga para chicos o Manga shōnen. Este tipo de manga va dirigido a un público adolescente, siendo mayoritariamente jóvenes varones. Tiene un alto contenido de acción.

Lady's comic

Hentai o manga erótico.

Me centraré principalmente en el manga shōjo, en el lady's comic y en el Hentai para ver las distinciones que se hacen dependiendo de edad y género. En referencia al 
Hentai, comentaré más ampliamente en el siguiente capítulo. Por otra parte, me parece importante el dividir el público al que va dirigido, ya que las temáticas y el contenido son distintos. Este tipo de distinciones perpetúa las relaciones de género, donde se estipula qué es lo considerado idóneo para cada edad y género.

\subsection{Manga shōjo}

En Japón las adolescentes son grandes consumidoras de manga. Las chicas tienen menos presión para entrar en la universidad y por lo tanto más tiempo de ocio que dedican a este tipo de lecturas. De los varones se requieren buenas notas para llegar al mundo universitario por tanto más esfuerzo y menos tiempo libre. Son las adolescentes las que disponen de más tiempo libre para leer cómics, los varones leerán más manga en su periodo universitario que es cuando ya no tienen esa presión social tan grande. (SCHODT: 1983)

El shōjo es el cómic dirigido a chicas adolescentes. Este tipo de manga se establece en el panorama japonés en los años 50 . Tiene su gran despegue a partir de los años 70. Al igual que en el shōnen, las temáticas están muy definidas y se basan en estereotipos de género muy marcados. Son cómics con trazos no muy agresivos y presencia floral en las viñetas. La trama normalmente se basa en historias de amor, creando la idealización del amor romántico y de la pareja en las jóvenes usuarias de este tipo de género. (BERNDT: 1996) Éste no es un contexto muy distinto del español. Aunque las adolescentes españolas no consuman shōjo, sí que lo hacen con sus homónimos como son las revistas o novelas de adolescentes. Puede ser el caso de las revistas "Superpop", "Bravo", "Nuevo Vale" o la saga de novelas "Crepúsculo" donde se potencia la idealización del amor. (ANÓNIMO: 2012)

Uno de los primeros manga shōjo aparece en los años 40 con el nombre de "Ribon no kishi" del autor Osama Tezuka, uno de los grandes autores de manga en Japón. La obra en España se traduciría con el nombre de "Chopy y la princesa". Como ocurre con muchas mangas de éxito, éste sería llevado al anime a finales de los 60 . El argumento se puede llegar a entender como un intento de transgredir los roles de género, aunque finalmente se quede simplemente en un intento. (ACEBRÓN. MERINO: 2005). 
Como comenta Bernt:

"En esta ópera prima encontramos ya uno de los temas que luego iban a predominar en el manga para jovencitas: la ruptura de las rígidas normas sexuales. La idea esencial consiste en jugar con la ambivalencia sexual como estrategia contrapuesta a la norma de la realidad." (BERNT, 1996:98)

El argumento de la historia se centra en una princesa, la princesa Zafiro. En la historia, al nacer los bebés se les asignan en el cielo el sexo dándoles una mora azul a los niños y una manzana a las niñas. La protagonista, la princesa Zafiro, recibe por error la mora azul. Es aquí cuando comienza esta transgresión ya que se le asigna una mora a una supuesta niña. Pero es una transgresión parcial, ya que se dice que esta princesa, la princesa Zafiro, tiene dos corazones. Uno de ellos es bravo y valiente, como supuestamente deben de ser los hombres y otro de ellos es cariñoso, adjetivo asignado por género a las mujeres. La protagonista es criada como un niño varón por sus padres, los reyes, ya que al existir la ley sálica sólo un príncipe puede gobernar. Esconden el sexo de la niña para que pueda gobernar en un futuro. Zafiro no parece tener ningún conflicto con respecto a esta asignación ya que ella misma tiene atributos asignados tanto al género femenino como al masculino.

Durante toda la historia se está jugando con esa idea establecida de mujer u hombre. Ya en el primer capítulo del anime unos bandidos persiguen a la princesa Zafiro para saber si es hombre o mujer. Con esto lo que se pretende es que no llegue al trono si se demuestra que es mujer.

El primer capítulo del anime se llama "Ángel y príncipe". Transcribo parte del diálogo que se lleva a cabo entre estos villanos y la princesa Zafiro, lo que me parece relevante.

- $\quad$ Princesa Zafiro: “¿Por qué me han atacado?”
- $\quad$ Villanos: "Porque queremos saber si es niño o niña”
- $\quad$ Villanos "Si eres hombre con esta sustancia te pondrás azul, si no color
púrpura"9

Se ve clara la necesidad de establecer a qué sexo pertenece esta persona. Más aun, se establece la diferencia de género entre colores. Si es hombre la sustancia que le tiran se convertirá en azul y si es mujer se convertirá en rosa.

\footnotetext{
${ }^{9}$ http://www.youtube.com/watch?v=htFBwWX4g_M
} 
Con todo, se están exaltando los atributos asociados a los hombres, como puede ser el de valentía y lucha, que son los atributos que la princesa utiliza para salir bien parada de sus aventuras. No se encuentran sin embargo mangas en los que hombres tomen el rol de género asociado a las mujeres. Finalmente, un ángel quita el corazón de Zafiro supuestamente masculino, por lo que se queda sólo con el femenino, siendo éste el final del manga. La princesa se enamora del príncipe de un reino vecino y programan su boda. De todas formas, hay que tener en cuenta que el cómic de "Chopy y la princesa" fue escrito en los años 50, lo que hace muy difícil romper con los roles estipulados y las asignaciones por género.

Otro ejemplo muy parecido al de "Chopy y la princesa" es el de "La rosa de Versalles". El título original de esta obra es Berusaiyu no Bara. "La rosa de Versalles" es un manga, publicado en 1972. Después pasa a convertirse en anime, contando con muchísima popularidad. La autora es Riyoko lkeda. Esta mangaka, artista japonesa de manga, pertenece al grupo de las 24 , nombre que hace referencia a un grupo de mujeres nacidas todas alrededor del año 24 del periodo Shōwa. ${ }^{10}$ (SHAMOON: 2007).

La trama de "La rosa de Versalles"11 se desarrolla en vísperas de la Revolución Francesa. Uno de los personajes principales, hija de un oficial del ejército francés, es educada como hombre bajo el nombre de Óscar. Aunque es mujer, ha sido criada como varón y por lo tanto cuenta con toda la aceptación social que se tiene por ser hombre y militar en aquella época en Francia. Aun en este escenario, se vuelve a la idea de amor romántico. Óscar se enamora de su sirviente André, siendo esta relación imposible por varios motivos. Aparte de pertenecer a clases diferentes, Óscar no se

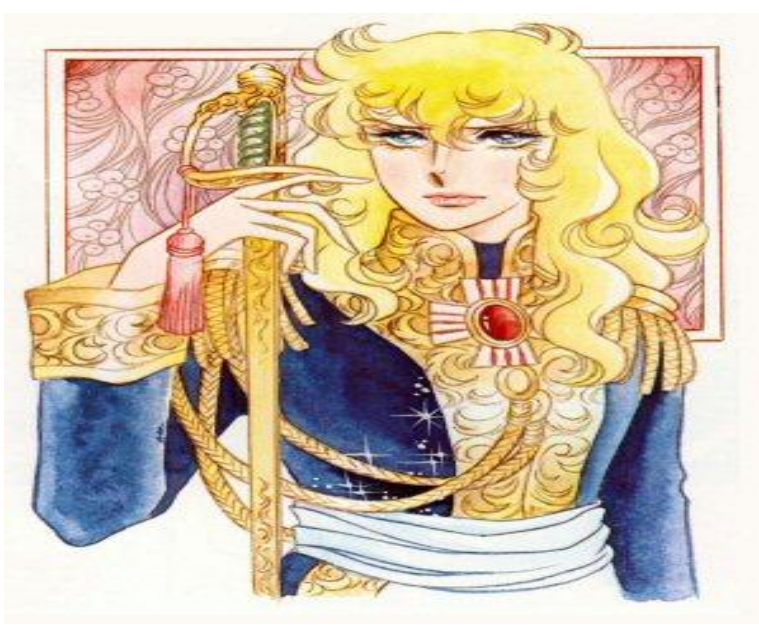

\footnotetext{
${ }^{10}$ Periodo Showa es el periodo de la historia japonesa correspondiente al reinado del emperador Shōwa (Hirohito) que abarca desde el 25 de diciembre de 1926 al 7 de enero de 1989

${ }^{11}$ La imagen corresponde al personaje principal de "La Rosa de Versalles", Óscar, vestida de militar.
} 
quiere permitir tener sentimientos por un hombre, aunque en el cómic se plasma la contradicción interna por la que pasa la protagonista. Lo que se pretende es volver a propiciar esa idea de amor idealizado e imposible por parte de Óscar y la clara división de género y clase que existe (ÍBIDEM: 2007).

Ya que este tipo de cómics va dirigido a chicas adolescentes, se sigue potenciando esa idea de amor romántico y de superioridad masculina, siendo Óscar bien vista en los círculos sociales por su supuesta masculinidad.

Por otra parte, aunque sea de forma puntual, también se producen a veces transgresiones de esta idea de amor heterosexual y mitificado. Éste puede ser el caso del manga y anime Sailoor Moon. En España fue emitida con el nombre de "Sailor Moon", o "Luna, la princesa guerrera". Con nombre original "Bishōjo Senshi Sērā Mūen", Sailoor Moon es una serie de anime japonés que tuvo una expansión mundial en los años 90, perteneciente también al subgénero de shōjo. En el cómic aparece una relación lésbica entre dos de las protagonistas. Por supuesto, aparece una idealización del amor con el personaje principal masculino, pero la aparición de esta pareja lésbica significa un avance en este tipo de género. (ALLISON: 2006)

Existen grandes diferencias entre los cómics y dibujos animados enfocados a un público varón adolescente, de un público femenino de la misma edad. La forma de expresarse es distinta ya que en el manga para adolescentes varones no se usan tanto la introspección de los personajes. No se ve los pensamientos internos para que haya una empatía entre la persona lectora y el personaje principal. Se potencian mucho más los sentimientos en los cómics y anime dirigidos a chicas que en los dirigidos a varones. También las viñetas se estructuran de forma distinta, teniendo en los dibujos para chicos una estructura clara y en los cómics para chicas hay viñetas más grandes que otras en tamaño, o que incluso se superponen entre sí. (BERNDT: 1996)

\subsection{Lady's comics}

A partir de los años 90 aparece un nuevo género en el manga-anime, llamado lady's comic. Este nuevo género está enfocado a un público de mujeres adultas jóvenes. Este género contiene escenas eróticas explícitas y trata en su trama la vida diaria. Sin embargo, aunque se tengan relaciones sexuales, no se está transgrediendo con la idea del shōjo. Sigue habiendo una idealización del amor y se mantiene ese final feliz que también aparece en las historias para chicas adolescentes. 
Los lady's comics van dirigidos a chicas adultas, entre la veintena y la treintena. En este tipo de cómic se sigue potenciando el amor romántico como ocurre en los cómics para chicas adolescentes. Incluso la portada es muy parecida en los lady's comics a los manga shōjo Sin embargo, el lady's comic surge con un propósito claro. Se supone que las adolescentes no debieran consumir porno, por lo que no existen escenas eróticas o sexuales en los shōjo. En cambio, a la edad adulta ya está socialmente aceptado el consumir pornografía y por ello que aparecen este tipo de cómics. Por tanto, la mayor diferencia entre lady's comics y shōjo, es que en el lady's comics aparecen escenas sexuales que no tienen cabida en el segundo. Para asegurarse de que las adolescentes no consumen este tipo de cómic, aparece una advertencia en la portada avisando de que contenido es sólo para adultos. Se hace patente cómo la sexualidad sólo es permitida para chicas que ya han cumplido la mayoría de edad, no siendo posible en niñas más jóvenes. Como sucede en la cultura española, la sexualidad está vetada y es tabú en determinadas edades. (NAPIER: 2000)

\section{Divisiones difusas en Manga-Anime en la representación de género.}

Today is my farewell party

To love?

$\mathrm{N}-\mathrm{O}$.

Inside am I a man? A woman?

I strike a pose as one

And the other grows bored.

Well,

When the next page is turned

Another me.

Mine izu main (Mine is mine) 1986 (46) en (ROBERTSON: 1998: 47)

El epígrafe de más arriba corresponde a un álbum de fotos de una otokoyaku, actriz del Takarazuka. El Takarazuka es un teatro musical representado sólo por mujeres. Se puede ver cómo esta actriz niega el ser encasillada en un rol masculino o femenino. 
En la cultura japonesa la idea de género es menos estricta a la hora de ser representada que en otras como puede ser la española. Existen varios componentes a nivel histórico que así lo corroboran. Dos de ellos son Takarazuka revue y el teatro Kabuki.

El takaruka es un teatro sólo representado por mujeres, donde toman los roles tanto masculinos como femeninos, también en la vestimenta. Por otra parte, en Japón también ha existido desde comienzos del siglo XVII el teatro Kabuki. En el teatro Kabuki en un principio las mujeres representaban roles de género masculino y viceversa. Esto se permite hasta el 1629, cuando es prohibido. A partir de ese momento serán los hombres los que harán tanto los papeles masculinos como los femeninos. (ROBERTSON: 1998: 51)

Al estar implícito en la cultura japonesa, esto también estará plasmado en los mangas y animes, donde en ciertos materiales también se jugará con la idea de género.

Éste podría ser el caso de la serie anime Ranma 1/2, creación del autor Rumiko Takashasi, publicado entre 1987 y 1996. En primer lugar tendrá un formato manga para después pasar también al anime. Ranma, el personaje principal, es un joven practicante de artes marciales. En uno de los viajes para convertirse en un maestro de estas artes, llega con su padre a las fuentes de Jusenkyo. Si una persona cae en estas fuentes, cada vez que se moje con agua fría adopta el físico de la persona ahogada en ellas anteriormente. El padre de Ranma cae en una fuente donde murió ahogado un oso. En el caso de Ranma cae en el de una chica joven, de su misma edad aproximadamente. Por tanto, el cómic se desarrollará en la dualidad de Ranma entre su aspecto de mujer y hombre. Siempre que Ranma entre en contacto con el agua fría, adoptará el físico de una chica y en contacto con el agua caliente, volverá a tener su aspecto de varón. ${ }^{12}$ Ranma por tanto entra en conflicto con su

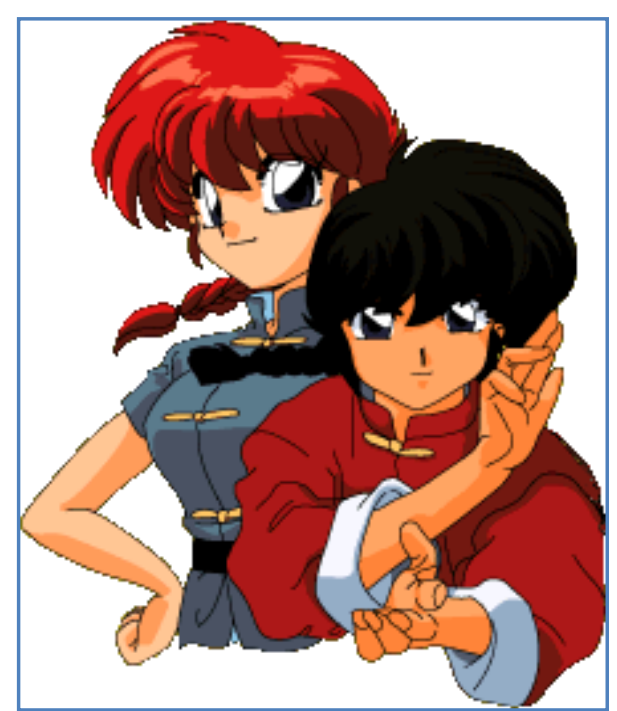
identidad, aunque él se considera un hombre que en ciertas circunstancias tiene un cuerpo de mujer. (HAHN AQUILA: 2007)

Ranma se puede entender como una ruptura con la idea fija de género, donde una persona puede representar tanto el género masculino como femenino. Aunque en este

\footnotetext{
${ }^{12}$ La imagen corresponde a las dos formas de representar a Ranma, tanto en chico como en chica.
} 
cómic se podría jugar mucho con la flexibilidad que tiene el género, están muy remarcadas las características supuestamente asignadas a hombres y mujeres.

En el capítulo 49, Ranma se golpea en la cabeza con una piedra. Esto le lleva a creerse una mujer y a comportarse de la forma que es esperada por ella en relación a los cánones de género. El título del capítulo es «¿Estoy guapa? La declaración de Ranma mujer». Sólo el título del mismo deja ver que no se va romper con las asociaciones de género sino que se van a perpetuar. Mujer y belleza van unidas en la misma frase. Ranma mujer está preocupada por su belleza, a diferencia de Ranma hombre Por ejemplo, en el mismo capítulo Soun Tendo, el padre de Akane dice a Ranma

"Ranma no me alegra tu nueva conducta pero debo admitir que cocinas muy bien" 13

Con su nueva conducta se refiere a su comportamiento femenino. Se puede ver que aunque se juegue con la idea del género, vuelve a haber una jerarquía clara de los roles. El comportamiento masculino está mejor valorado socialmente que el femenino.

Aunque hay ruptura, se sigue manteniendo una idea clara de los roles estereotipados tanto en el manga como en el anime. Algo parecido ocurrirá en la mayoría de Hentai que paso a analizar en el cuarto capítulo.

En resumen, en este capítulo he realizado una revisión cronológica del desarrollo del Manga - anime, tanto en el contexto japonés como en el español, trazando, de esta forma un contexto en el cual situar el Hentai, tipo de producción artística que abordaré en el siguiente capítulo. En éste trataré de trazar una historia del mismo, contemplando diferentes tipologías y temáticas que se tratan.

\footnotetext{
${ }^{13} \mathrm{http}: / /$ www.youtube.com/watch?v=Ob9S8_c9h9
} 


\section{Capítulo III. Hentai}

\section{Qué es Hentai.}

En este capítulo paso a describir brevemente el contexto histórico- cultural del eromanga en Japón y los tipos de Hentai, como una contextualización para un posterior análisis de tres Hentai en el capítulo IV.

La palabra hentai proviene del significado "metamorfosis" o "anormalidad". Esta palabra tiene una connotación negativa para los japoneses y está asociada a lo sexualmente pervertido. Este tipo de género se caracteriza por descripciones sexuales gráficas y explícitas e historias que muy a menudo incluyen actividades sexuales (como vimos para el lady's comics). (PEREZ, 2009)

En el caso japonés, hentai manga/anime es una subdivisión de una categoría mucho más amplia, habiendo otros cómics que también contienen relaciones sexuales como puede ser el caso del lady's comics. Sin embargo, en inglés la palabra hentai ha pasado a significar el género de ero manga como un todo. Lo mismo ocurre con la palabra en castellano. Hentai es por tanto un préstamo lingüístico que se utiliza para referirse a los cómis eróticos japoneses. El Hentai ha pasado de ser una palabra nipona para convertirse en el contexto occidental como manga erótico japonés. (MCLELLAND: 2006)

\section{Contexto cultural del Hentai en Japón}

El Hentai tiene unas características comunes con el manga. Una de ellas es que su precio es bajo y esto hace que su consumo sea muy extenso y al alcance de todo tipo de público. Otra de las características es su tamaño pequeño y fácil de usar, por lo que puede ser leído en cualquier espacio, desde un transporte público hasta un parque. Muchos Hentais tienen una tapa distinta que encubre su contenido. Por la tapa pueden parecer cómics sin ningún contenido erótico pero en su interior tener un contenido explícitamente sexual. (ALLISON: 2000)

El Hentai se enfrenta al mismo problema que el manga, ya que en estos momentos su consumo es mayoritariamente por internet y esto produce un decrecimiento de las compras. Por otra parte, la utilización de internet hace que muchas personas consumidoras puedan acceder a todo tipo de porno en la web, entre ellos el Hentai. (THOMSON: 2010) 


\section{Historia del Hentai}

Es a principios de siglo pasado cuando el Hentai comienza a ser más popular en Japón entre las clases trabajadoras. La proliferación de periódicos y revistas de precio asequible hizo que la lectura se convirtiera en una forma de ocio entre todo tipo de gente, surgiendo el llamado "boom del Hentai". No es sin embargo hasta los años 60 del siglo XX cuando se populariza en EEUU y por extensión en Europa. (BERNDT: 1996)

\section{Tipos de Hentai}

El Hentai como el Manga tiene variedad de público y por lo tanto variedad de temáticas. Realizaré una breve descripción de estos subgéneros. Sin embargo, estas categorías no son estancas sino que pueden encontrarse varias en un mismo cómic.

\subsection{Incesto}

Como comenta Anne Allison en "Permitted and prohibited desires" en el caso de la sociedad japonesa el incesto está especialmente mal visto entre madre e hijo. En Japón la exigencia académica desde edades tempranas es muy alta. Existe mucha presión en el alumnado para estar a la altura de las exigencias. El papel de la madre es fundamental en este caso para que el alumno llegue al nivel de la clase. Digo alumno y no alumna, porque la exigencia en las niñas es menor. Por tanto en la sociedad japonesa existe un vínculo muy fuerte entre madre e hijo, por lo que un mayor miedo de que se den casos de incesto entre ellos. (ALLISON: 2000) No pasa así con la relación padre- hija. Quizá por ello sí se puedan encontrar manga erótico como el de “"Voice of Submission II Gehenna” donde sí se da el incesto entre padrehija. 


\section{1 Ámbito escolar}

Muchas de las temáticas se desarrollan en un ámbito escolar. Para el contexto japonés el colegio es muy importante. Al igual que en el manga, también en el Hentai muchas escenas son representadas en este entorno. La idea de la estudiante como icono sexual ${ }^{14}$ es también muy utilizada. (NAPIER: 2000) Adjunto unas viñetas donde se puede ver claramente esta utilización de la estudiante como fantasía erótica.

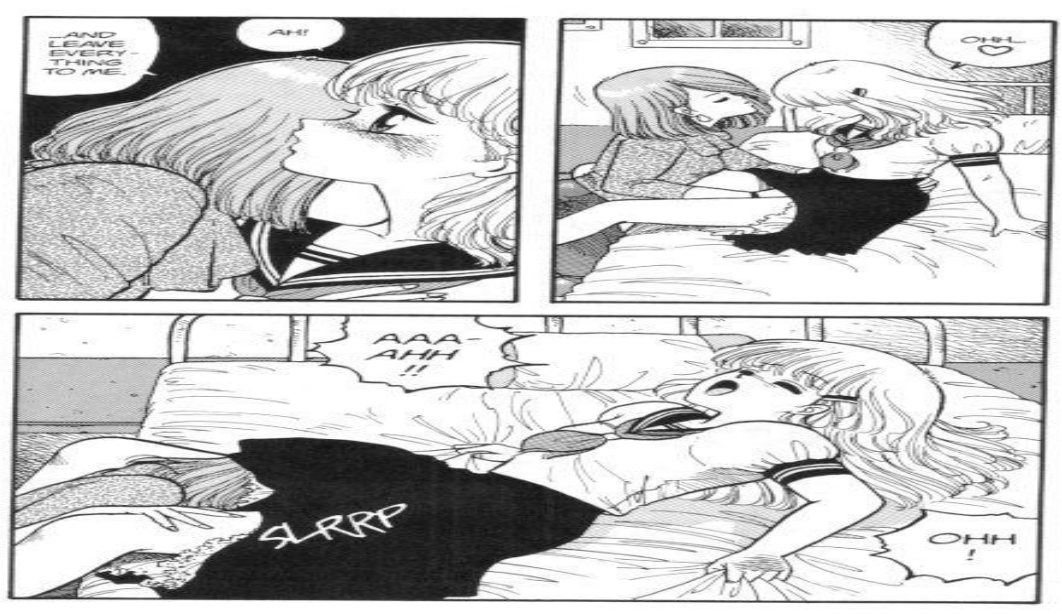

\subsection{Futanari}

En el cómic futanari aparecen personajes intersexuales, transgénero y travestis. Un gran número de cómics futanaris se basan en mujeres que tienen pene que nace desde la vulva, pueden ser penes que emerjan con la excitación sexual o que se mantengan de forma continua. Existen sin embargo variantes donde se dan casos de hombres que son disfrazados de mujeres como puede ser el caso de "Boy Soprano" que analizaré en el cuarto capítulo.

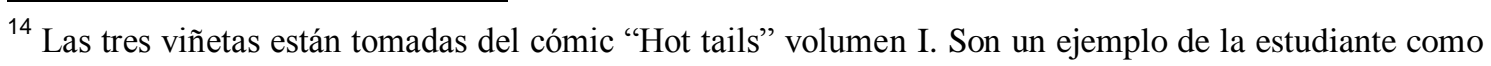
icono sexual.
} 


\subsection{BDSM}

Las siglas BDSM provienen de bondage, dominación, sadismo, masoquismo. En el subgénero del BSDM se dan relaciones de dominación- sumisión, sadomasoquismo o bondage (ataduras) $)^{15}$, aunque no tienen por qué darse todas a la vez. Adjunto una imagen de un ejemplo de bondage.

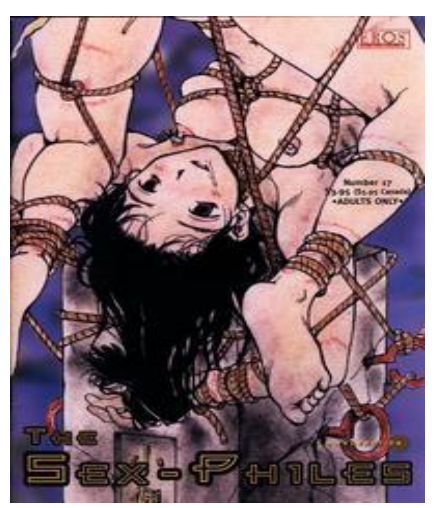

\subsection{Zoofilia}

Dentro del Hentai, otro de los subgéneros que se encuentran es el llamado bestialidad, también conocido como zoofilia. Existen relaciones sexuales entre humanos y animales pero no tienen por qué ser siempre así. Muchas otras veces, también se puede presentar el caso de una persona-bestia o animal antropomórfico como el de la imagen ${ }^{16}$. En la terminología japonesa, se denomina "Furry" a este acto Este tema está tratado más ampliamente en el análisis del cómic "Bondage Fairies".

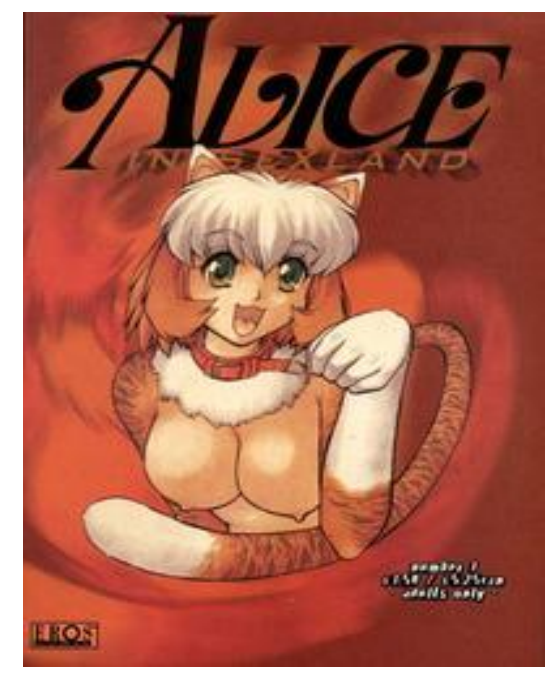

\footnotetext{
${ }^{15}$ Imagen de portada del volumen 17 del cómic “The Sex-Philes”. Ejemplo de prácticas de Bondages

${ }^{16}$ Imagen de portada del volumen 3 del cómic "Alice in sexland". Ejemplo de animal antropofórmico, usado en las temáticas de zoofilia.
} 


\subsection{Lolicon}

En el caso del lolicon se dan relaciones sexuales intergeneracionales. La palabra lolicon proviene de "complejo de lolita". Este complejo hace referencia al libro "Lolita" de Vladimir Nabokov donde un adulto mantiene una relación sexual con una niña preadolescente (BERNDT: 1996). Normalmente en el subgénero del lolicon se presentan relaciones de varones adultos con niñas prepúberes como en el caso de la novela. La diferencia de edad puede ser hasta el doble o triple entre la niña y el adulto.

\subsection{Relaciones homosexuales}

Existen asimismo en el Hentai relaciones homosexuales. Serían los subgéneros llamados yaoi y yuri. En el yaoi se producen relaciones sexuales entre hombres y en el yuri entre mujeres.

Se podría entender a partir de estos subgéneros que la cultura japonesa es una cultura abierta a la homosexualidad, ya que se tratan relaciones homosexuales en sus cómics. La realidad sin embargo es otra. Tanto en el caso del yaoi como del yuri estos géneros están orientados para el sexo contrario. Es decir, en el yaoi donde se mantienen relaciones sexuales entre hombres está orientado hacia un público femenino, a diferencia del yuri en el cual hay relaciones homosexuales entre mujeres y está orientado a un público masculino. De todas formas, estos dos tipos de género han ido evolucionando desde su nacimiento en la década de los 80 , pasando de ser dedicado a un público minoritario a tener mayores ventas. (ACEBRON, MERINO: 2005)

\subsubsection{Yaoi}

El término yaoi es un acrónimo de tres frases: yama nashi, ochi nashi y imi nashi (sin climax, sin finalidad, sin sentido). Esta terminología se adaptó para referirse a historias sexuales entre hombre-hombre. El acrónimo derivado de esta frase se refiere a la naturaleza de estas historias donde existe una falta de contenido y desarrollo. (TOKU, 2007:28) 
Las relaciones sexuales en el yaoi no son muy explícitas ${ }^{17}$, basándose más en las relaciones personales y en los problemas de pareja. Al igual que en el manga, se está haciendo una diferenciación en la forma de enfocar las relaciones sexuales ya que este tipo de género va dirigido a chicas adolescentes o mujeres. (NAGAKUBO: 2005 en TOKU, 2007:29)

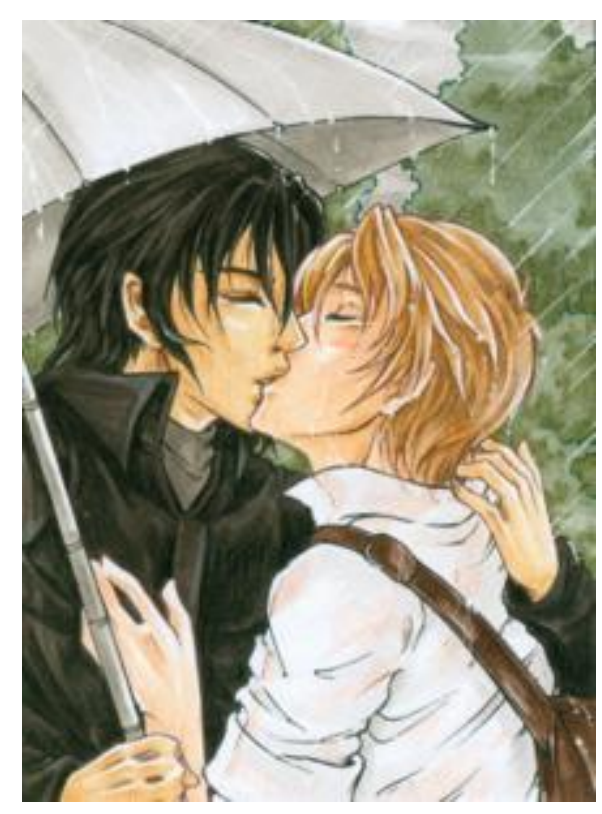

\subsubsection{Yuri}

Yuri significa lirio en japonés. Es a partir de los años 70 cuando aparece el uso de la palabra para referirse a historias que contienen relaciones entre mujeres. De todas formas, la palabra como tal no fue acuñada hasta 1990, coincidiendo con la entrada de este subgénero a EEUU y Europa. Por tanto, la palabra yuri como hentai lésbico ha sido más utilizada en un contexto occidental. Antes del uso de esta palabra, no existe ninguna documentación sobre qué nombre se utilizaba para estas historias donde existían relaciones sexuales entre mujeres. Sin embargo el yuri, al igual que el yaoi, no estaba enfocado a mujeres lesbianas. Los primeros cómics yuri eran dibujados por hombres para una clientela masculina. En estos momentos el yuri es consumido

\footnotetext{
${ }^{17}$ Imagen representativa del género yaoi, tomada de la Wikipedia en inglés (artículo Yaoi) y publicada originalmente en la revista alemana Animexx.
} 
principalmente por mujeres y también hay mujeres entre las autoras de este género. (THOMPSON, 2010) $^{18}$

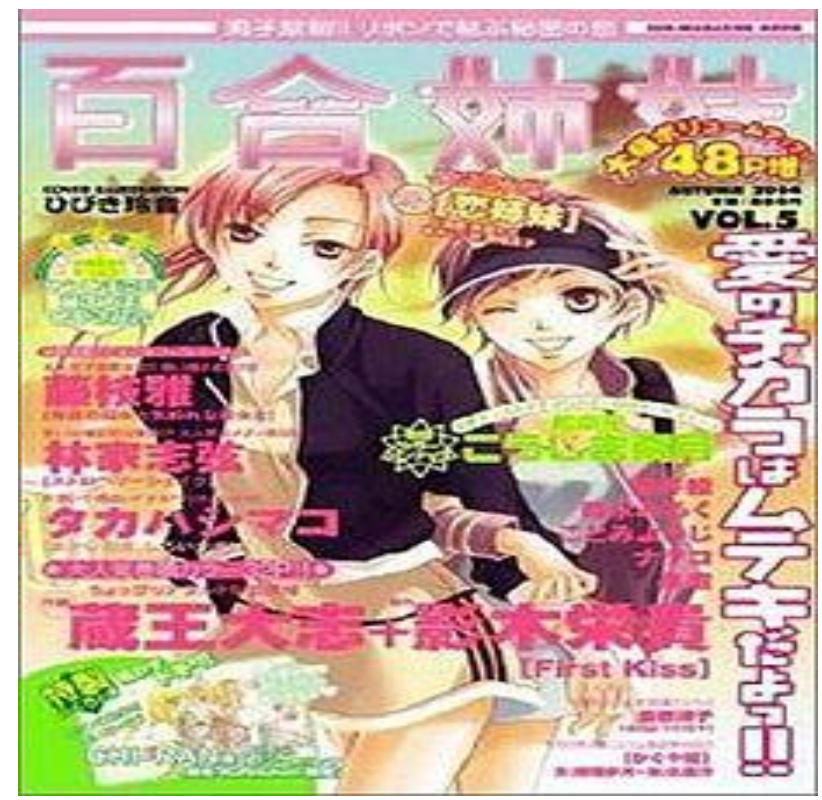

Después de una contextualización del material de Hentai, paso en el siguiente capítulo a analizar tres cómics Hentai con diferentes prácticas sexuales no normativas, enmarcados dentro de las temáticas lésbica, incesto y futanari entre otras.

\footnotetext{
${ }^{18}$ Imagen tomada de la Wikipedia en ingles (artículo Yuri_(genre). Cubierta del número de otoño 2004 de la revista Yuri Shimai, ilustrada por Reine Hibiki, referenciando a la serie de novelas yuri Maria-sama ga Miteru.
} 


\section{Capítulo IV. Análisis de cómics Hentai}

\section{Análisis de Hentai}

"Yo creo en el potencial del porno para ayudar a las mujeres a seguir desarrollando nuestra revolución sexual, que es una batalla que debe estar siempre viva, que no acabó ni mucho menos en los años setenta, ya que entonces no hizo más que empezar. Creo que a las mujeres nos puede beneficiar mirar películas explícitas. Las mujeres que somos libres sexualmente podemos encontrar en ellas imágenes que nos inspiren a seguir en nuestra búsqueda de placer. Nos puede ayudar a enriquecer nuestras fantasías. Podemos descubrir gustos que no sabíamos que teníamos antes." (LUST, 2009: 36).

Como comenta Erika Lust, éste es para mí uno de los aspectos más positivos con respecto al Hentai, el que se potencien las fantasías de todo tipo, el que se busquen nuevos gustos, el que en definitiva se utilicen las fantasías para una sexualidad más completa. Autoras y autores coinciden en que las fantasías sexuales son una parte fundamental para una sexualidad satisfactoria. Como comenta Carol Vance:

“... hemos reiterado que el órgano más importante, en los seres humanos, está localizado entre los oídos" (VANCE, 1982 en WEEKS, 1985:19)

Jeffrey Weeks reitera esa idea de las fantasías como parte esencial de la sexualidad:

"La sexualidad tiene tanto que ver con las palabras, las imágenes, los rituales y las fantasías como con el cuerpo". (WEEKS, 1985:20)

Las fantasías enriquecen la sexualidad. Éstas pueden provenir de distintos lugares, y uno de ellos sin duda es el material pornográfico, entre los que se encuentra el Hentai. Éste es uno de los motivos para analizar estos cómics desde una perspectiva feminista, para ser entendidos como otras formas de sexualidad que podemos utilizar en nuestras prácticas sexuales o relegarlas sólo al ámbito de las fantasías.

Así, desde mi enfoque como consumidora de Hentai en una cultura española, veo aquí una forma de entender la sexualidad y el género desde otra perspectiva, que pretendo desarrollar a través del análisis de estos tres cómics que a continuación presento. En 
cierto modo y con muchas restricciones, considero que afecta positivamente a la idea del género y al cómo se vive la sexualidad a través de la plasmación de estas fantasías. Los tres cómics de los que realizo un análisis crítico son: "Voice of Submission II Gehenna", "Bondage fairies Extreme" y "Boy Soprano".

\section{Tres cómics, tres opciones de fantasía sexual}

"Recuerda que nuestra batalla pretende que seamos aceptadas en la plenitud de nuestra diferencia, y no a causa de que prometamos comportarnos como todo el mundo" (NESTLE: 1988 en MARQUÉS Y OSBORNE, 1991)

Una de las características comunes entre estos tres Hentais es la división entre la afectividad y el sexo. En todos los casos, hay relaciones sexuales donde existe una división entre el amor romántico y las relaciones sexuales. Este tipo de cómics también es visto por muchas mujeres, que a diferencia de otro tipo de material orientado a ellas, no se crea una idealización del amor y una unión obligatoria entre sexo y sentimientos. Asimismo, en los tres casos se dan relaciones sexuales no consentidas aunque las características específicas de cada uno varían notablemente. La elección de estos tres Hentais se debe a que en los tres se dan prácticas sexuales no normativas con elementos transgresores que pasaré a desarrollar más adelante.

Por otra parte, tanto en la portada de "Bondage Fairys Extreme" como de "Voice of Submission II Gehenna" aparece una advertencia, "Adults only". Se constata la idea de que la sexualidad es sólo para adultos y se hace presente en la portada también, xcluyendo la sexualidad en la infancia (FOUCAULT: 1977). Paso a describir a continuación los cómics anteriormente nombrados.

\subsection{Análisis cómic "Bondage fairies Extreme"}

"Bondage fairies Extreme" es una obra escrita e ilustrada por el artista japonés Kondom. El primer capítulo de esta serie fue publicado en Estados Unidos en octubre 
de 1999 por Eros Comic $^{19}$, siendo el último capítulo editado en marzo de 2003. La historia se divide en quince capítulos, con una extensión entre diecinueve y veinticinco páginas por cada uno. La mayoría del cómic está publicado en blanco y negro, aunque las primeras hojas suelen estar en color.

El autor ha publicado varias historias con los mismos personajes, Pfil y Pamila. Se trata de dos hadas del bosque caracterizadas como mujeres con alas, que trabajan como cazadoras, siendo su tarea principal la protección del bosque. En "Bondage fairies Extreme", Pfil tiene un desgarro vaginal mientras Pamila le está insertando un dildo por la vagina. Las dos van a visitar a la nueva médica del bosque. Lo que no saben es que Urushira, la nueva médica, es la expareja de Pamila. Después de examinarla, Urushira aconseja a Pfil que se quede esa noche en la clínica para comprobar cómo evoluciona la herida. Ya en la habitación de la clínica, a solas las dos, Pamila va a buscar un vaso de agua. Antes, aconseja a Pfil que no salga en toda la noche de la habitación, ya que Urushira por la noche es peligrosa. Sin explicar por qué, dice que está enferma. ${ }^{20}$

\section{El personaje de Urushira:}

Urushira tiene distintas relaciones sexuales en la historia. Tiene relaciones sexuales tanto como con mujeres- hadas como con animales machos. Se puede ver cómo en el capítulo 3 ella es dueña de su sexualidad. No necesita a ninguna otra persona para satisfacer sus deseos, está teniendo sexo con un gusano y disfrutando con ello. Como comenta Carol Vance:

"El feminismo debe insistir en que las mujeres son sujetos sexuales, actores sexuales, agentes sexuales" (VANCE, 1989: 47).

Y es así como vemos en un principio a Urushira. Esta supuesta independencia sexual cambia totalmente según avanzan las páginas. Lo que comienza siendo una independencia se convierte en un una enfermedad, en una ninfomanía, una adicción al

\footnotetext{
${ }^{19}$ En mi caso, he accedido al visionado de este cómic a través de una página web: http://ehentai.org/l/e/t/b/

${ }^{20}$ La frase textual en inglés es: "Urushira, was... well, she got kind of... sick, I guess you'd say" Capítulo 2 Página 14
} 
sexo incontrolada. Empieza a tener sentido lo que le comenta Pamila a Pfil sobre Urushira, que está "enferma". Está "enferma" porque está poseída por sus ganas de tener sexo. En la página 9, en el capítulo 3 Pamila le dice a Urushira "estás enferma Urushira, como siempre has estado". Se reitera la idea de enfermedad por necesidad sexual, por depravación. ${ }^{21}$ Se refuerza esa idea de negatividad y sexualidad en la página 13, al preguntar Urushira a Pamila si la dejó porque se convirtió en demasiado puta e insaciable para ella. Aparece la idea de abandonarla por demasiado activa sexualmente. ${ }^{22}$ Urushira es la mala de la historia, porque es la que folla mucho y sin control.

Esta idea de Urushira como un ser maligno e insaciable de placer se repite de nuevo en el capítulo 7, en la conversación que tienen el mono y la tortuga. La tortuga es amante de Urushira y el mono ha sido paciente suyo. Urushira tiene una doble personalidad. Durante el día es agradable y se preocupa por los demás ${ }^{23}$ como la define Pamila. Durante la noche se supone que es una ninfómana adicta al sexo que hace cualquier cosa para ello. Se ve cómo por conseguir sexo, incluso viola tanto a Pfil como a Pamila. Ni la tortuga ni el mono pueden entender cómo puede ser la misma persona una chica dulce y angelical que se convierte en una ninfómana sexual de noche. ${ }^{24}$ Se está de nuevo criminalizando a Urushira por su vida sexual. Sin embargo, se puede encontrar una diferencia con otros cómics donde aparecen violaciones. A diferencia de otros materiales donde la violación por hombres está consentida, la violación por parte de Urushira es censurada por los demás personajes.

\section{El personaje de Pamila:}

Pamila es la expareja de Urushira. Cuando van a la consulta de la médica, no se puede imaginar que se trate de la consulta de Urushira. Ésta última todavía no ha

\footnotetext{
${ }^{21}$ La frase textual en inglés es: "You're sick Urushira, just as you always were” Capítulo 3 Página 9

${ }^{22}$ La frases textuales en inglés son: "Why did you show me such sexual ecstasy?... and then leave me?" "Was it because I became too slutty and insatiable for you to handle?” Capítulo 3 Páginas 13 y 14

23 “Gentle, carying” Capítulo 4 Página 19

${ }^{24}$ Tortuga: "it's killin' me. I'm gettin' out while I still can” Mono: "I... I don't believe it" Mono: "sigh" "my sweet little angel of mercy...? Like that?!" Capítulo 7 Página 8
} 
superado la ruptura con Pamila y aprovecha la noche que pasan en su clínica, para encerrar tanto a Pamila como a Pfil y abusar de ellas sexualmente.

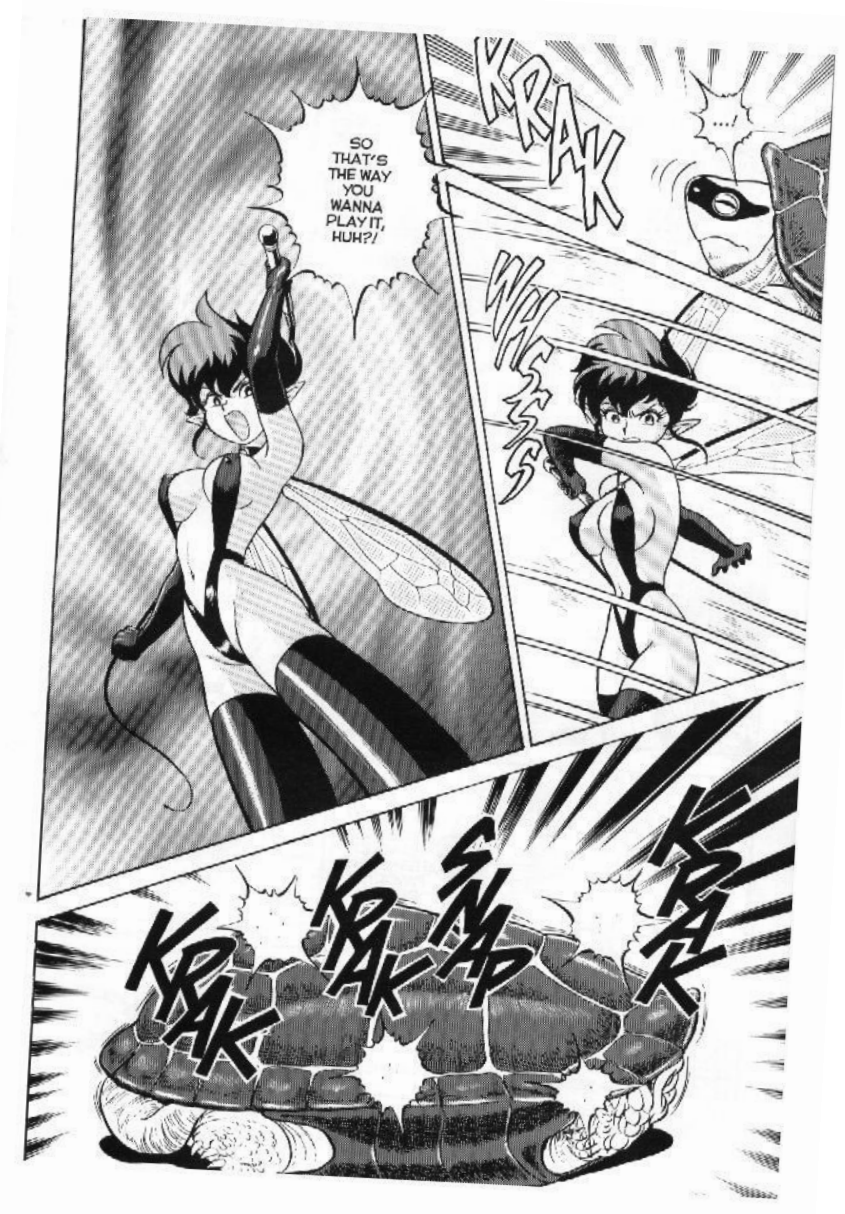

El personaje de Pamila es un personaje fuerte ${ }^{25}$ con unas connotaciones no asociadas a las mujeres por género. En el segundo capítulo, Pamila va a ver a Urushira y ésta intenta atraparla y manda a una tortuga para conseguirlo. Pamila hace uso de su látigo contra la tortuga para intentar escapar, como se ve en la imagen de más arriba. El látigo no está asociado a una mujer por género. En este momento se esperaría de una mujer que fuera sumisa y la actitud que desarrolla Pamila es totalmente opuesta.

Por otra parte, en el capítulo 12 mientras Urushira viola a Pamila, utiliza un argumento para validar esta actuación, el de que Pamila está disfrutando. Este tipo de comentarios se utiliza para validar las violaciones, aunque en este caso lo chocante es que no es dé de un hombre a una mujer, si no de una mujer a otra.

\footnotetext{
${ }^{25}$ Imagen mostrando a Pamila, del capítulo 3, página 16
} 
En el capítulo 14 se descubre que Pamila es bisexual, habiendo tenido relaciones con hombres anteriormente a Urushira y Pfil. Tanto Pfil como Pamila rompen con la dicotomía homosexualidad, heterosexualidad. Además de ser entendida la bisexualidad como una categoría desestabilizadora (GUASH, VIÑUELAS, 2003)

Por otra parte, tanto Pamila como las otras dos personajes femeninos, son dibujadas con tacones altos, grandes pechos y largas piernas, basándose en los cánones tradicionales de mujeres. De esta forma no se intenta reivindicar otras formas de vestir y otros cánones de belleza. (LUST: 2009)

\section{El personaje de Pfil:}

Pfil es uno de los personajes principales de la historia. Es la pareja de Pamila y las dos van a la veterinaria para que le trate un problema vaginal. Finalmente, acaba convertida en el juguete sexual de Urushira, la expareja de Pamila. Urushira la retiene contra su voluntad ${ }^{26}$ y la obliga a tomar drogas, donde tiene sueños sexuales donde nunca llega al orgasmo.

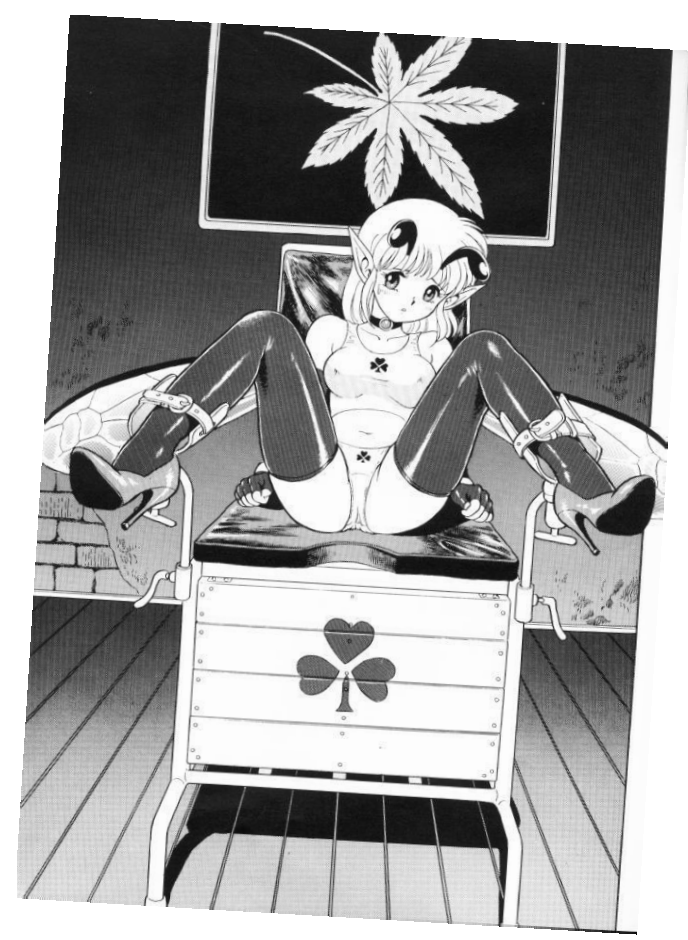

\footnotetext{
${ }^{26}$ Imagen de Pfil retenida por Urushira, del capítulo 5, página 7
} 
En el capítulo 14, el penúltimo de esta historia, el personaje de Pfil toma un camino totalmente inesperado. Durante los capítulos anteriores, Pfil se encuentra en la actitud más vulnerable, se ve cómo es cuidada por Pamila en los primeros capítulos, preocupándose por ella y estando Pamila en una situación protectora. Por otro lado, durante toda la serie es utilizada sexualmente por Urushira para dar celos a Pamila. Sin embargo, en el capítulo 14 Pfil se empodera y se hace dueña de ella misma y de la situación. Consigue escapar a los efectos de la droga que le suministra Urushira y aun atada y en una situación vulnerable, se planta contra su captora y le niega el placer sexual con el que antes contestaba. Dice textualmente que no siente nada. ${ }^{27}$

Al final del mismo capítulo, un mono paciente de Urushira rompe el techo y rapta a Urushira, llevándosela contra su voluntad. Se la lleva al bosque y abusa sexualmente de ella. Es aquí cuando se ve al personaje de Pfil se ve empoderado. Logra liberarse de las cuerdas que le atan y salir en ayuda de Urushira. Pfil se convierte en un personaje necesario, ya que Pamila está encadenada y es ella la que salva a Urushira del mono. No necesita un "héroe" para salvar a Urushira, se convierte ella misma en heroína.

\section{Elementos transgresores:}

Existen muchos elementos en el cómic que perpetúan el sistema patriarcal a través de cómo son representadas las protagonistas y la situación. Sin embargo, se encuentran varios elementos transgresores.

Uno de ellos es el uso de arnés que aparece por primera vez en el capítulo 3 y es usado varias veces a lo largo de la historia. Por otra parte, se dan escenas de sadomasoquismo. En el capítulo 7, Pamila es representada atada con unas cuerdas de pies y manos.

Otro de los elementos transgresores es el de relaciones sexuales con animales. Siempre se ha considerado tabú y depravable este tipo de actos. Como aparecen en la compilación de Carol Vance, existe el miedo de tener fantasías sexuales con un determinado tópico que después se conviertan en realidad.

\footnotetext{
${ }^{27}$ La frase textual en inglés es: “I don't feel a thing”. Capítulo 14 Página 14
} 
"Yo creía realmente que, si una imagen descansaba en los rincones de mi mente pasaba al centro de la escena, ello me llevaría inevitablemente a hacerla realidad. Así que cada vez que soñaba con follar con pieles, no con carne, me horrorizaba." (VANCE: 1989, 198).

Por otra parte, me parece importante incidir en la idea de fantasías para una plenitud sexual. Coincido con la idea expresada en el mismo párrafo del citado anterior:

"Yo nunca había comprendido que una idea podía fascinarme profundamente, y sin embargo, no disfrutarla, en absoluto, si la probaba en la vida real; no había comprendido que la fantasía podía darme una herramienta para representarme aspectos diferentes de mi propia conciencia sexual en desarrollo (o la de mi amante) sin ir más allá. También me permitía una libertad no sujeta a los límites de mi cuerpo o a las fronteras de mi consciencia." (ÍBIDEM: 1989, 198)

Cualquier fantasía puede ser válida y aceptable si se basa en una fantasía. Asimismo, el ver otras realidades puede dar paso a la visibilización de otras sexualidades. La invisibilidad crea la no existencia.

Otro tema transgresor en este cómic es la ruptura de un tabú como es la pureza, la pulcritud. En el capítulo 10 se juega con la idea de puro e impuro cuando Urushira le masturba a Pfil con uno de sus pies. Los pies, asociados a una zona sucia del cuerpo, están siendo utilizados con connotaciones sexuales. (DOUGLAS: 1996) 


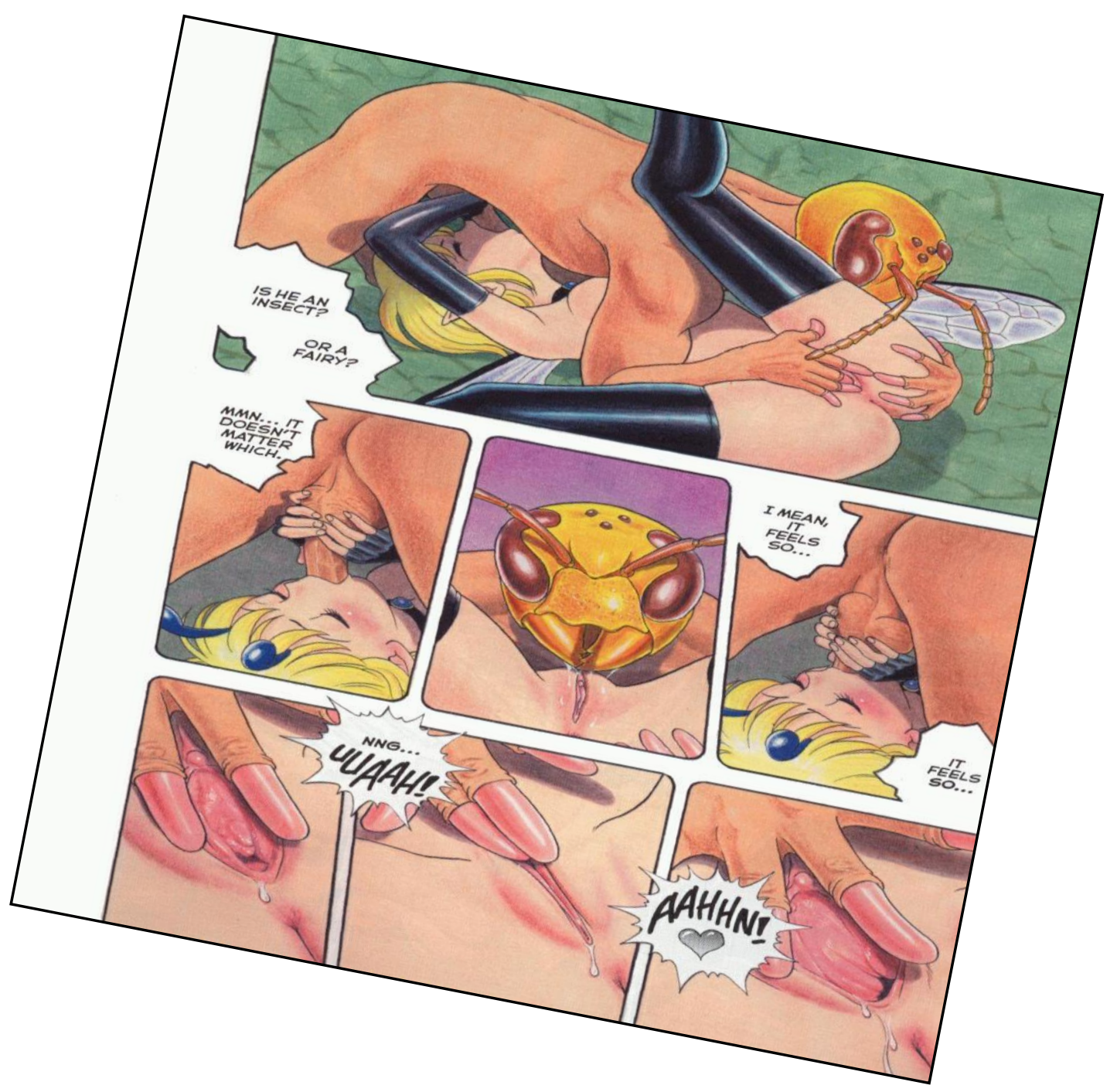

Asimismo, otro elemento cuestionado es la categorización del género. En el capítulo 8, Pfil está teniendo fantasías sexuales debido a la droga que le ha dado Urushira. Está follando con alguien con cuerpo de hombre y cabeza de insecto, como se puede ver en la imagen de más arriba. Ella se pregunta si es un insecto o un hado, a lo que se contesta que no importa. ${ }^{28}$ Lo importante es el placer, el dejarse llevar. También rompe con la idea de hada igual a mujer. No se pregunta si es un hombre, sino si es un "hado". Al pensar en hada, se está pensando en un hada femenina. En este caso, no corresponde para nada con el imaginario social que se tiene de ello.

\footnotetext{
${ }^{28}$ Las palabras de Pfil en inglés son: "Is he an insect? Or a fairy?" "It doesn't matter which" Capítulo 8 Página 4 (mostrada en la imagen)
} 


\subsection{Análisis cómic "Boy Soprano"}

"Boy Soprano" es una obra escrita e ilustrada por el artista japonés Wanyan Aguda. Esta obra fue publicado en 2000 por Fujimi Comic ${ }^{29}$. La historia consta de un único capítulo, dividido en once partes. La totalidad del cómic está publicado en blanco y negro.

El título de este Hentai ya nos da una idea clara a lo que hace referencia. Soprano es una de las voces del coro que se encuentra dentro del rango de mujeres. En la primera página el personaje principal, Akira, nos explica la situación. Sus padres mueren en un accidente de tráfico cuando él es pequeño y se queda a cargo de una familiar, su tía que vive con su hija. Desde el principio, la tía trata a Akira como a una niña, vistiéndolo como tal. Asimismo, también abusa sexualmente de él, lo que hace también su prima, de la misma edad que él.

No he encontrado ningún Hentai en el que haya relaciones entre padre e hijo, aunque sí entre madre e hija. En el caso de "Boy Soprano" aunque madre e hija no tienen relaciones sexuales entre ellas, sí que comparten el mismo amante y se encuentran a veces en el mismo espacio. Son observadoras de las prácticas sexuales de la otra ${ }^{30}$. A continuación, se puede ver en la imagen cómo tanto la tía como la prima están manteniendo relaciones sexuales con Akira en el mismo momento.

\footnotetext{
${ }^{29}$ En mi caso, he accedido al visionado de este cómic a través de una página web: http://www.animephile.com/hentai/boy-soprano.html

${ }^{30}$ Portada de Boy Soprano, capítulo 1, donde se ve a Akira junto a su tía y prima.
} 


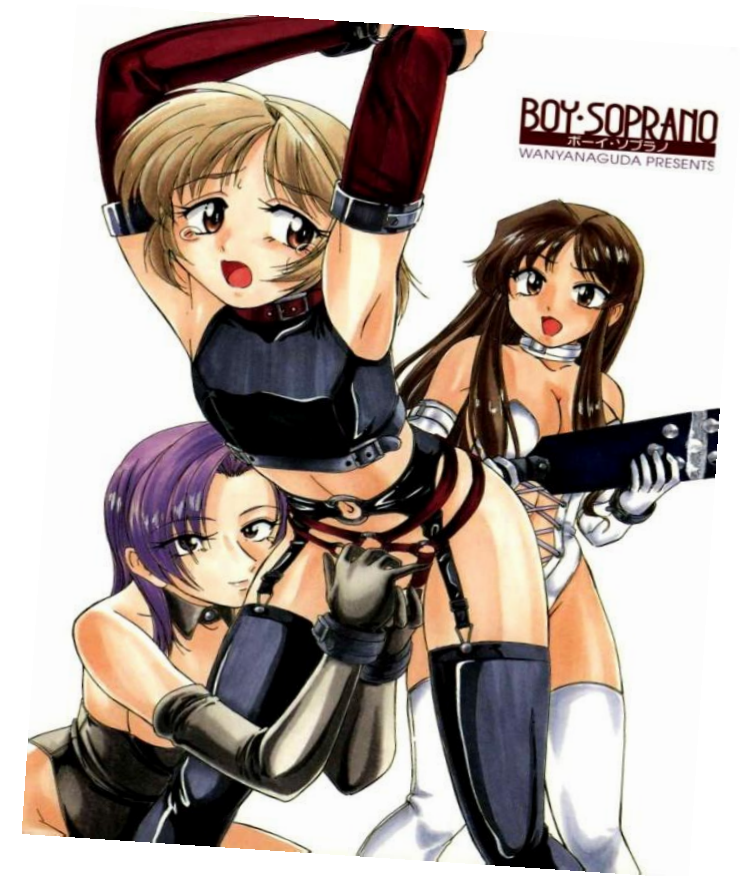

El personaje de Akira:

Este cómic es un claro ejemplo de cómo se puede romper con lo tradicional de las ideas de género. Al final del primer capítulo se sabe que Akira va a ser cambiado de colegio y que irá al colegio donde da clase su tía y asiste su prima, un colegio sólo de chicas. Cuando Akira llega a su nuevo colegio, dos niñas hablan de él. Dicen que es muy guapa. Las palabras textuales son "she is very beatiful". Se puede ver cómo la asignación sexual es cambiante dependiendo de las expectativas que se tengan de esa persona.

El personaje de Akira puede ser entendido como una identidad queer desde algunas perspectivas:

"In one of the many definitions of queer that she provides in her book Tendencies, Eve Sedgwick describes this term as referring to "the open mesh of possibilities, gaps, overlaps, dissonances and resonances, lapses and excesses of meaning when the constituent elements of anyone's gender, of anyone's sexuality aren't made (or can't be made) to signify monolithically" - in other words, any way of being in the world (or imagining such being) that differs from what is considered "normative." (BULLOCK, 2006: 667) 
"Los queer pretenden desestabilizar los límites que dividen lo normal de la desviación y organizarse contra la heteronormatividad. Tratan de combinar impulsos contradictorios para unir a personas que han sido incitadas por la sociedad a sentirse perversas, raras, parias, diferentes". (GUASCH, VIÑUELAS, 2003: 106)

En "Boy Soprano" no se busca una identidad de género reconocible. Se rompe la relación de un sexo, un género, además de mantenerse en los márgenes de lo socialmente aceptado.

"El entorno social presiona los sujetos no normativos para que se adapten; en el marco de una sociedad sexista el sujeto mismo vive como necesaria la encarnación de una identidad de género reconocible." (MISSÉ, COLL-PLANAS, 2010: 18)

Asimismo, al estar Akira fuera de las expectativas de sexo y género, se encuentra con una serie de problemas como comenta Missé y Coll- Planas. Aunque no se aborda de forma crítica, sí se hace patente el malestar que siente Akira por ser vestido de chica cuando su anatomía tiene un pene. En el capítulo cuatro, Akira dice que todo el mundo se ríe y se burla de él. ${ }^{31}$ Se hace patente que al no encajar con lo normativo, sufre las consecuencias de ello.

"No se aborda el debate del coste que implica, al conjunto de la población, encarnar el género, de la violencia que genera y del sufrimiento que produce a las personas que no pueden ser clasificadas según la estructura binaria" (ÍBIDEM, 2010: 17)

\footnotetext{
${ }^{31}$ La frase textual en inglés es: "Everybody made fun of me and bullied me all the same..." Capítulo 4 Página 1
} 


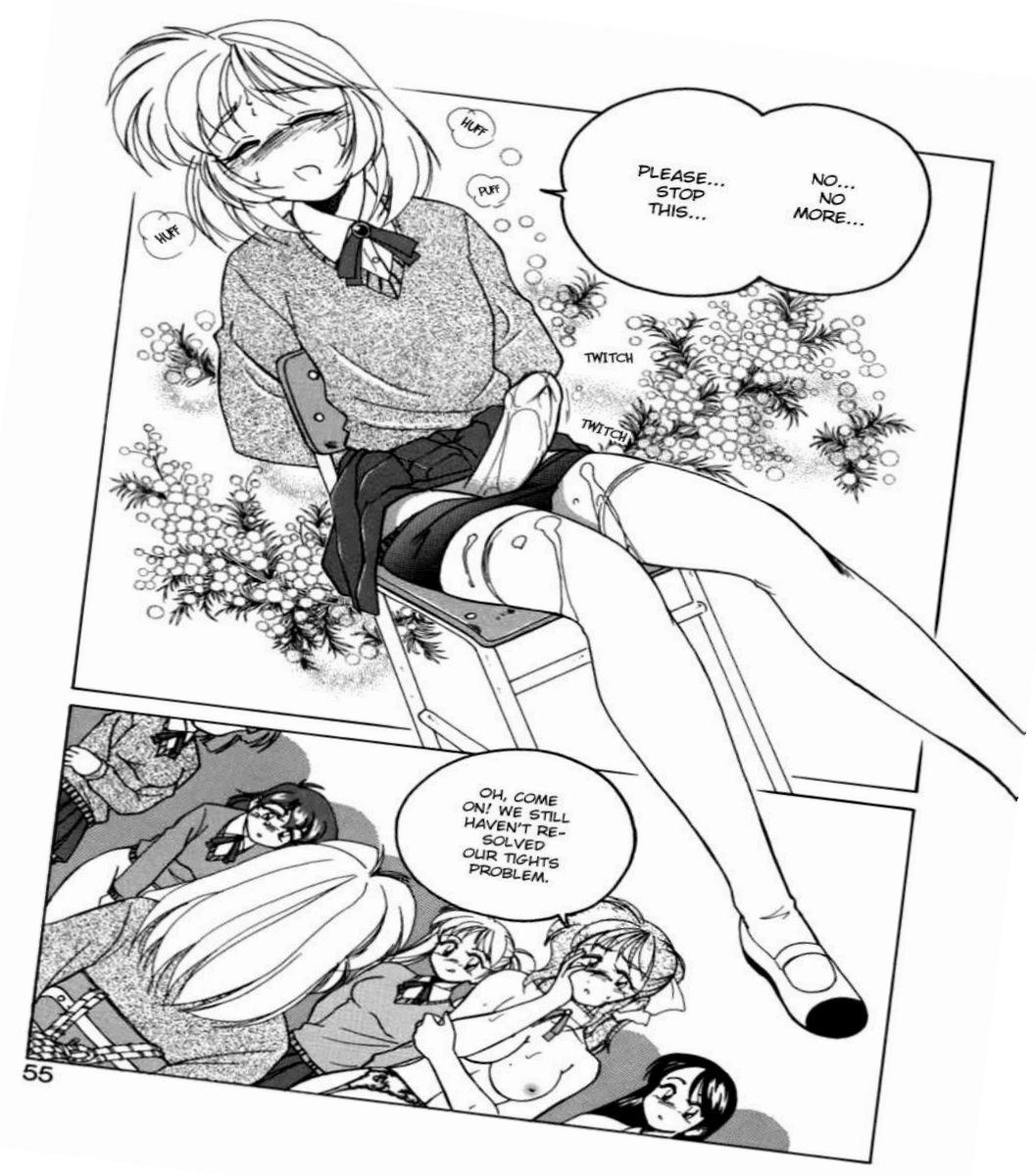

Sí que se puede observar que Akira se convierte en una especie de "mono de feria", un ente extraño que todas sus compañeras quieren constatar que tiene pene, como vemos en la imagen de más arriba donde está atado a la silla del colegio mientras sus compañeras lo observan ${ }^{32}$. Se convierte en un objeto sexual de sus compañeras, que quieren verle el pene y jugar con él. Aunque Akira no está de acuerdo, eso no hace que ellas cesen. En el tercer capítulo es sometido a abusos por sus compañeras de clase. En la última página de la tercera parte una alumna le dice a la profesora que la fiesta se ha acabado, haciendo referencia a que Akira no puede follar más, después de haber estado abusando de él todas sus compañeras. ${ }^{33}$

\footnotetext{
${ }^{32}$ Se puede ver claramente en la imagen, del capítulo 3, página 17

${ }^{33}$ La frase textual en inglés es: "Looks like the show is over, teach"
} 


\section{Elementos transgresores:}

También en "Boy Soprano" aparecen elementos transgresores, algunos de los cuales son compartidos con los otros cómics. Uno de los elementos comunes con "Bondage fairies" es la aparición de juguetes sexuales no convencionales. En la primera parte, la tía de Akira mete unas bolas por el culo a su hija y a Akira Chan mientras está habiendo penetración entre ellos. Asimismo, en la quinta parte del cómic se hace uso de un arnés de una chica a Akira.

El papel dominante en la relación sexual lo tiene la tía. Además, él es el niño indefenso y ella es la adulta. Podría entrar incluso dentro del rango de violación, porque Akira no quiere mantener relaciones sexuales con su tía y es obligado a mantenerlas. Existe una relación de poder invertida según los parámetros más comunes. La relación intergeneracional se suele dar de hombres a mujeres a diferencia de este caso.

"La verdadera curiosidad estriba en que, mientras que en la realidad la explotación la lleva a cabo, sobre todo, el hombre adulto sobre chicas jóvenes, muchas veces dentro y cerca del entorno del hogar, a menudo se ha considerado a los hombres homosexuales como los principales corruptores, hasta el punto de que en algunos registros los términos "homosexual" y "corruptor de menores" son equivalentes". (WEEKS, 1985:354)

En el caso de "Boy Soprano" no se utilizan ninguno de estos dos estereotipos para la relación intergeneracional. No se utiliza ni la que ocurre más frecuentemente, de hombre sobre chica joven, ni la del imaginario social que comenta Weeks sobre el homosexual varón.

Otro de los elementos subversivos es la utilización de prácticas sadomasoquistas, y juguetes relacionados con estas prácticas, esta vez en el entorno del colegio. En la segunda parte, la prima de Akira, Rika, le está haciendo a Akira una ruta por el colegio 
cuando le enseña el club de SM. Al igual que en los otros dos cómics, se dan relaciones sexuales enmarcadas en la periferia. Aunque en este capítulo se dan prácticas sadomasoquistas entre Akira, su prima y otras compañeras de colegio, no se podrían entender como tal, ya que una de las dos partes, en este caso Akira, no consiente esta relación.

"Foucault ubicó al sadomasoquismo dentro de la categoría de sexualidades periféricas, que serían aquellas que según él se producen lejos de la alcoba de los padres, no son reproductivas, no tienen por qué ser heterosexuales, ni monogámicas, ni suaves, ni entre personas de la misma edad, ni en pareja, ni en privado." (ARROYAVE, 2006)

"Es decir, que de manera significativa el SM crea un escenario en el que se dan formas de sexualidad que se desvían de la construcción social del sexo tan reforzada por los agentes de control social. Las sexualidades no normativas (homosexuales, intergeneracionales, sadomasoquistas, no monógamas), aunque no necesariamente presuponen la conciencia o intencionalidad de desequilibrar el orden establecido, lo desafían con su mera existencia." (ÍBIDEM, 2006)

En la tercera parte, la tía de Akira, tiene relaciones sexuales con su profesora del colegio, esta vez consentidas por las dos partes. En el cuarto capítulo la profesora de Akira tiene una reunión con éste y con su tía, que es también la directora del colegio. Desde el despacho, se abre una puerta que da acceso al club de SM. A diferencia del capítulo tres donde las relaciones no son consentidas por Akira, en el cuatro sí hay relaciones sadomasoquistas consentidas por las dos partes, proviniendo de la tía y de la profesora de Akira, como se puede ver en el dibujo. ${ }^{34}$

\footnotetext{
${ }^{34}$ Cuarta parte Página 4
} 


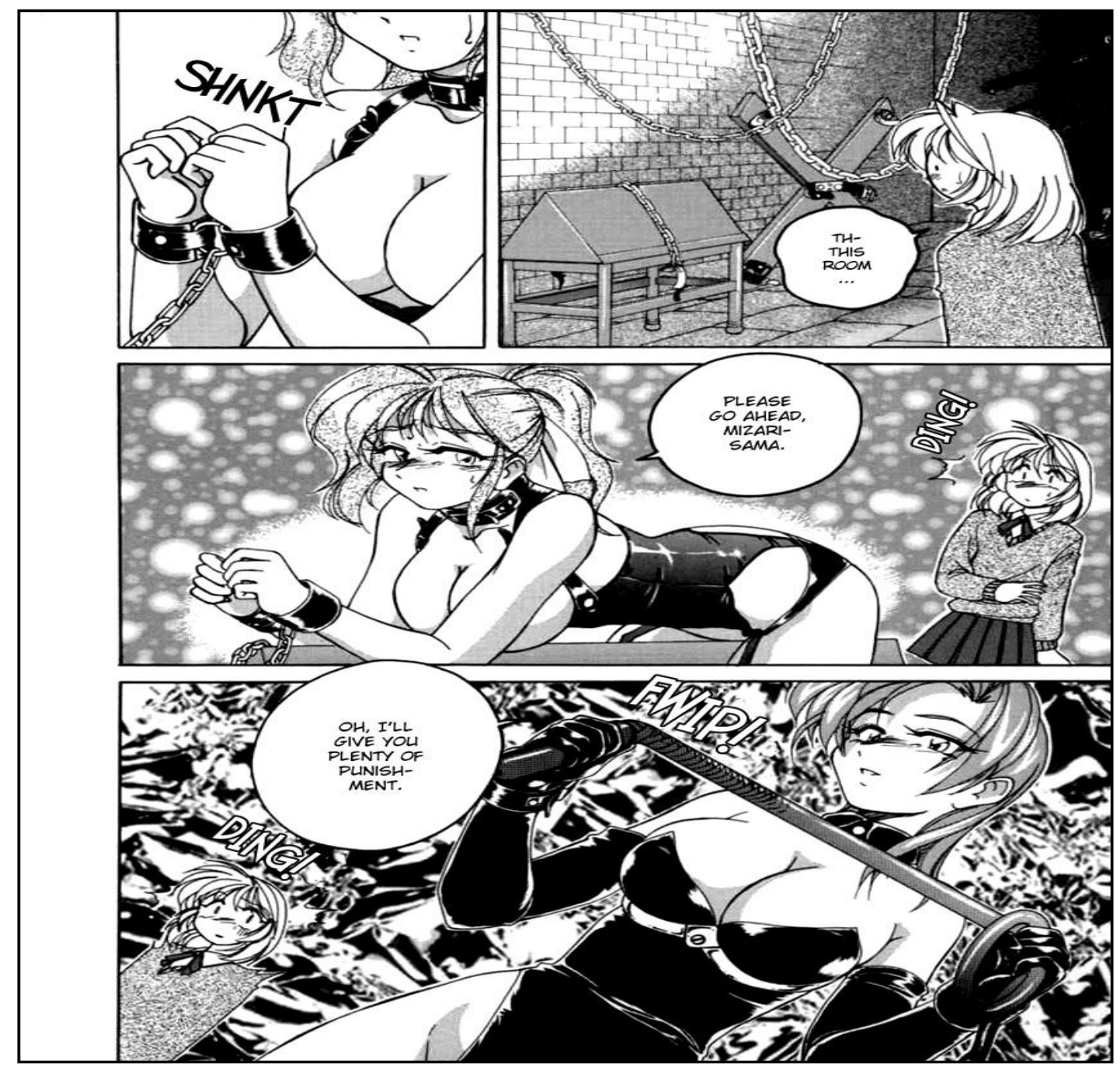




\subsection{Análisis cómic "Voice of Submission II Gehenna"}

"Voice of Submission II Gehenna" es una obra escrita e ilustrada por el artista japonés Mashumaro Juubaori. El primer capítulo de "Voice of Submission II Gehenna" ${ }^{35}$ fue publicado en Estados Unidos en noviembre del 2000 por Eros Comic ${ }^{36}$. El último capítulo de esta serie se editó en mayo del 2011. La historia está dividida en cinco capítulos, con una extensión de veintidós páginas por cada capítulo. La totalidad del cómic está publicado en blanco y negro.

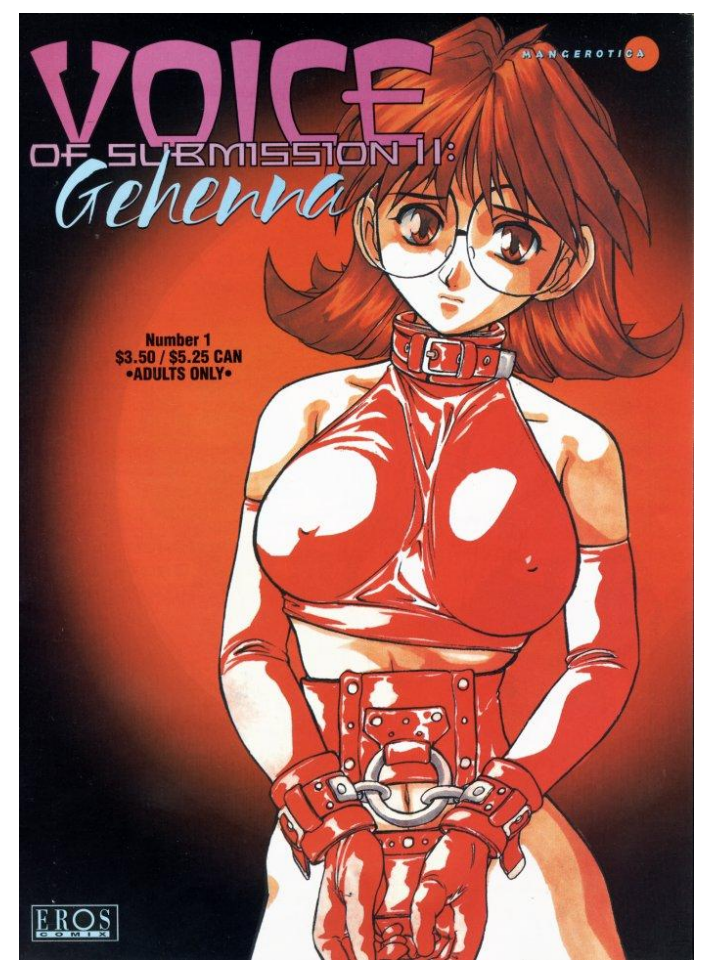

El cómic comienza con lo que parece un atraco a una chica en un parque de noche. Lo que comienza siendo esto, pasa a ser una violación del atracador. Como se puede ver en la página 6 del capítulo 1, existe una superioridad física del atacante, además de estar en posesión éste de un cuchillo ${ }^{37}$. Se ve una actitud indefensa por parte de ella,

\footnotetext{
${ }^{35}$ Imagen de la portada del primer capítulo, donde aparece la protagonista en actitud indefensa

${ }^{36}$ En mi caso, he accedido al visionado de este cómic a través de una página web: http://e-hentai.org/l/e/t/v/\#
} 
a diferencia de él que disfruta y tiene control de la situación. La víctima, Ryoko, al principio se resiste y le pide por favor al violador que no lo haga. Según van pasando las viñetas, la actitud de la víctima cambia. En la página 10 , se ve cómo Ryoko se da cuenta que está excitada por la situación que está viviendo, que debería ser denigrante pero se supone que está disfrutando por su respuesta corporal. En la imagen se puede ver cómo él la penetra mientras la mantiene presa, cogiéndola desde detrás por el cuello y por la cintura con un cuchillo. En esta situación, Ryoko se pregunta: “¿¡Estoy mojada de verdad?!”. ${ }^{38}$

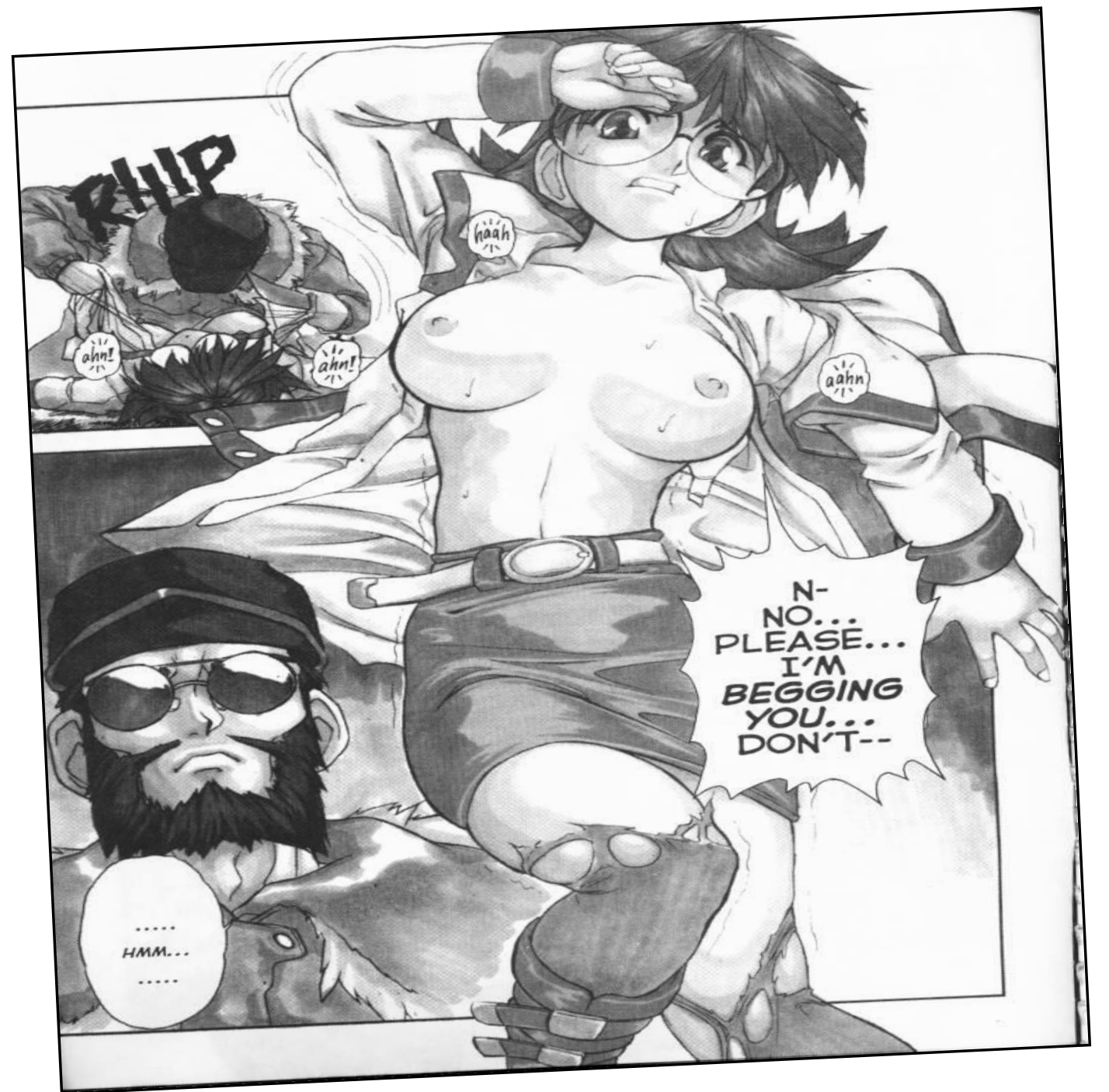

En la página 12 se ve cómo la actitud de la víctima ha cambiado totalmente. Pasa de implorar perdón a querer ser penetrada por el agresor. En un bocadillo se ve cómo

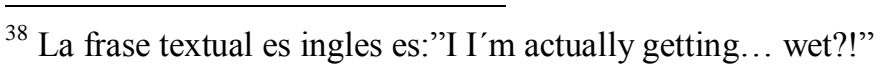


piensa "oh Dios... tu polla es tan grande... ¡No puedo...!" En el siguiente bocadillo sin embargo dice "Pero... ¡lo quiero! Estoy... estoy muy cerca... Voy a..."39

A partir del momento en el que la víctima está "disfrutando" de esa violación, se está consintiendo esa violación y se quita toda la carga que conlleva. Como comenta Mckinnon:

"Cuando una mujer acepta lo que se convertiría en violación si no lo aceptara, se transforma en sexo. Si las mujeres aceptaran el coito forzado como sexo, habría sexo voluntario para un mayor número de hombres (...) Ninguna mujer sería violada porque la violación sería sexo." (MACKINNON, 1987: 10).

Se le está exculpando al violador del acto cometido al tratar la situación como un acto de disfrute de ambos, como si fuera un acto consentido. En la página 13 Ryoko acaba diciendo literalmente "fóllame"40. Se pretende quitar la carga a la violación, al ser aceptada finalmente por ella. Como comenta Mackinnnon, feminista de la corriente antiporno, se está justificando en cierta manera la violación ya que después la chica piensa en ello otra vez y lo disfruta en cierta manera. Se desarrolla la idea de Mackinnon, de no convertirse en violación.

"La reacción tradicional hacia la víctima ha sido la de acusarla (blaming the victim) de provocadora del delito que se ha cometido contra ella, siendo la contrapartida de esta actitud la de absolver a los hombres de su responsabilidad hacia dicha víctima. " (MARQUÉS Y OSBORNE, 1991, 250).

Con respecto a la violación, es ella la que se siente mal por lo que ha pasado y lo esconde a su entorno. Tampoco hay una actitud de censura por parte de otros personajes como podemos encontrar en "Bondage fairies Extreme". La violación en este caso no se ve como un acto censurable o represariable.

\footnotetext{
${ }^{39} \mathrm{La}$ frase textual en inglés es: "oh God...your cock is so huge... I... I c-can't...!" "But... I want it! I...I'm so close... I'm..." Capítulo 1Página 12

${ }^{40}$ La frase textual en inglés es: "Fuck me, fuck meee!!” Capítulo 1Página 13 
Sin embargo, veo elementos de una forma de práctica sexual desestabilizante, subversiva.

\section{Elementos transgresores:}

Al final del capítulo, el violador deja a Ryoko inconsciente en el parque y le saca unas fotos. En el capítulo dos, la víctima accede a quedar con el violador ya que éste le está chantajeando con las fotos que había sacado después de la violación. Quedan en un parque para que él le dé los negativos. En el capítulo dos tienen relaciones sexuales en el parque, siendo la actitud de Ryoko distinta, accediendo a esta relación sexual. Al final del capítulo dos el violador se lleva a Rioko a otro lugar. En el capítulo tres están dentro de una casa, y es así cuando se descubre que el agresor es su padre. Hasta este momento, el padre había estado disfrazado con una barba, una peluca, gorra y gafas de sol. En este capítulo, Ryoko accede a tener relaciones sexuales con su padre, convirtiéndose en consentida esta relación de incesto.

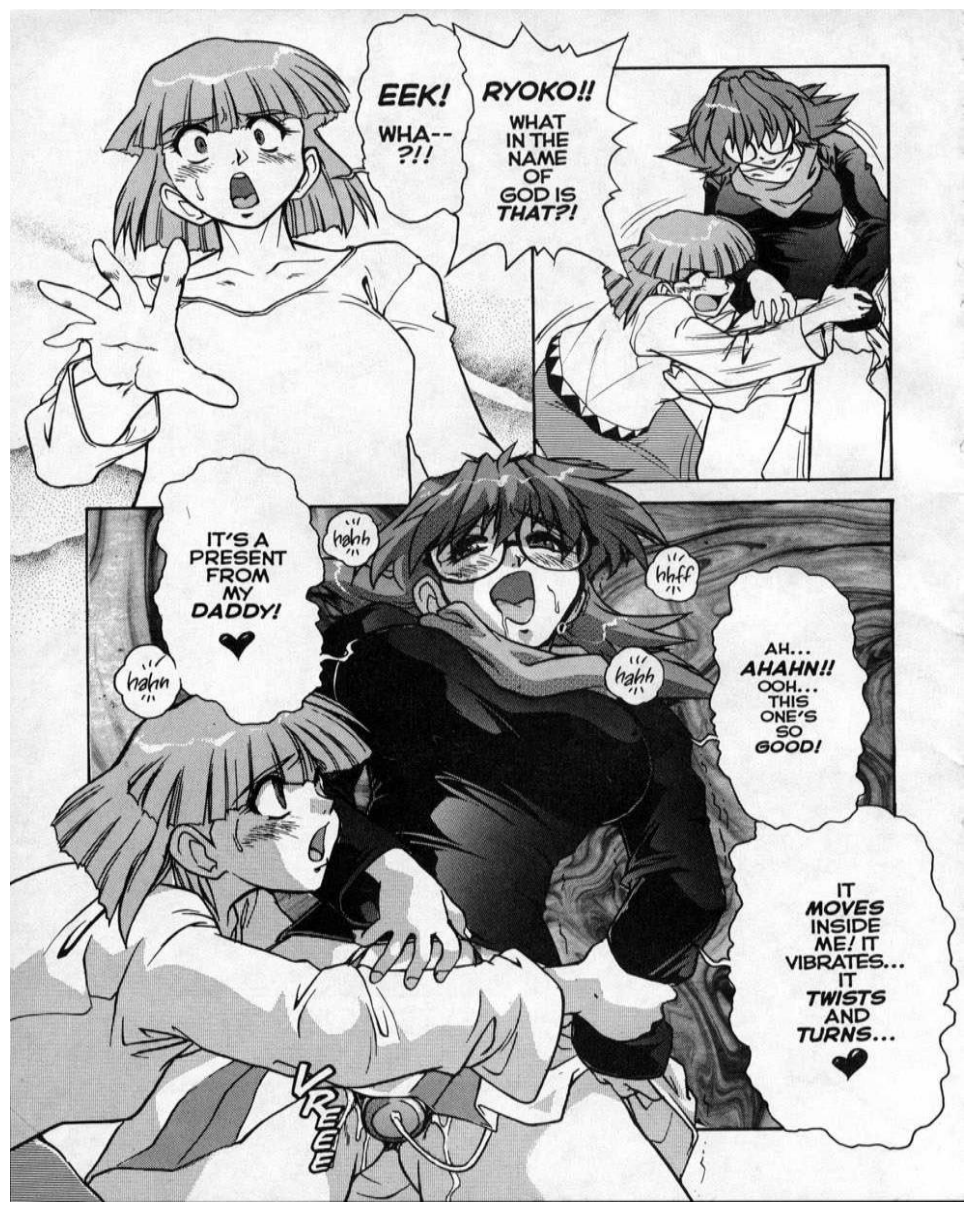


En el último capítulo Miyuki, amiga de Ryoko, está preocupada por Ryoko porque no sabe bien qué le pasa. En ese momento descubre que Ryoko lleva un vibrador metido dentro de la vagina, como se puede ver en la imagen de más arriba. Cuando Miyuki le pregunta qué es, Ryoko le contesta que es un regalo de su padre ${ }^{41}$. Miyuki no puede creer lo que su amiga le está diciendo, así que cuando Ryoko la invita a su casa para follar con su padre, ésta accede para saber qué es lo que ocurre. Cuando llegan a casa y Ryoko le dice que ha llegado a casa, el padre de Rioko le dice que se quite la ropa. $^{42}$

Uno de los elementos transgresores que encuentro es el del incesto. Es un tema tabú para nuestra sociedad que es tratado en este cómic. Incluso se juega con la idea de que el regalo del padre de Ryoko sea un juguete sexual, cosa nada normativa.Asimismo, existen otras prácticas sexuales no convencionales. En el capítulo 5, Ryoko chupa el ano de Miyuki mientras el padre de Ryoko la penetra. Existe mucho tabú en relación al ano y aquí Rioko está lamiendo el ano de su amiga, disfrutando con la práctica por motu proprio.

Por otro lado, se da una relación intergeneracional, al ser la relación sexual padre-hija.

Como comenta Gayle Rubin:

"Las sociedades occidentales modernas evalúan los actos sexuales según un sistema jerárquico de valor sexual. En la cima de la pirámide erótica están solamente los heterosexuales reproductores casados. Justo debajo están los heterosexuales monógamos no casados y agrupados en parejas, seguidos de la mayor parte de los demás heterosexuales. El sexo solitario flota ambiguamente. El poderoso estigma que pesaba sobre la masturbación en el siglo XIX aún permanece en formas modificadas más débiles, tales como la idea de que la masturbación es una especie de sustituto inferior de los encuentros de pareja. Las parejas estables de lesbianas y gays están en el borde la respetabilidad, pero los homosexuales y lesbianas promiscuos revolotean justo por encima de los grupos situados en el fondo mismo de la pirámide. Las castas sexuales más despreciadas incluyen normalmente a los transexuales, travestís, fetichistas, sadomasoquistas (...) y la más baja de

\footnotetext{
${ }^{41}$ La frase textual en inglés es: "It's a present from my daddy" Capítulo 5 Página 6

${ }^{42}$ Las frases textuales en inglés son: "Papa... I'm home!" "Ryoko? Take off your clothes and come here" Capítulo 5 Página 8
} 
todas, aquellos cuyo erotismo transgrede las fronteras generacionales." (VANCE, 1989: 136)

Haciendo referencia a la pirámide de Rubin, la sexualidad menos permitida, la más cuestionada, es la que transgrede las fronteras generacionales. En el caso de este cómic se da una transgresión de este tipo.

También Weeks analiza el tabú de las relaciones intergeneracionales.

"Si el sexo en público constituye un motivo de preocupación moral, el sexo intergeneracional es otro motivo, incluso más importante. Desde al menos el siglo XVIII, la sexualidad infantil ha sido convencionalmente definida como un tema tabú, en la medida en que la infancia se fue considerando cada vez más como una época de inocencia y pureza que debía guardarse a toda costa de la corrupción adulta”.(WEEKS, 1985: 354)

Se rompen las barreras de lo "normal" y se pone un pie en "la degeneración", se tratan temas tabús que trascienden por completo los convencionalismos como son el incesto y la relación sexual intergeneracional. Sin embargo, hay que matizar que son fantasías que no tiene por qué llevarse a la práctica. Ya que como comenta Raquel Osborne, esas ideas se pueden mantener entre las orejas, jugar con los límites sólo en nuestras cabezas:

“Las imágenes sexuales pueden utilizarse en el nivel de la fantasía y mantenerse en él, así como que los individuos puedan emplear la fantasía para coquetear con sentimientos peligrosos o que infunden temor, pero sin deseo alguno de experimentarlos en la vida real" (CALDERÓN, OSBORNE: 1990, 31)

A través de cómics como éste se anima a la gente a explorar sus fantasías y sus deseos, más allá de convencionalismos sociales y pensamientos políticamente correctos, a no tener miedo por tener una determinada fantasía, como puede ser el incesto. 


\section{Conclusiones}

"Que Sade fuera machista, objetualizador, que despreciara a las mujeres, que sus escritos estén impregnados de misoginia, no debe impedirnos apreciar tantos otros aspectos suyos que resultaron novedosos en su época y que aún hoy pueden tener validez, incluso en el terreno de la mujer." (OSBORNE, 1989: 89)

Finalicé la introducción de este trabajo de investigación citando a Raquel Osborne y para cerrar el círculo termino mis conclusiones con la misma autora porque el párrafo anterior me parece un buen reflejo de lo que significa para mí el Hentai. En este material erótico no me cabe duda de que existen muchos elementos denigrantes para las mujeres, vejantes y que tratan a éstas, nos tratan, más como objetos sexuales que como ciudadanas. También que mayoritariamente en el Hentai los cuerpos de las mujeres son entendidos como utilizables a la voluntad de los varones. Sin embargo, como he intentando exponer a lo largo de este trabajo, aún con estos elementos anteriormente citados, existen componentes que hacen una aportación en el terreno de la sexualidad plasmando prácticas sexuales no normativas.

Me gustaría en estas conclusiones el romper una lanza a favor del Hentai desde mi posicionamiento feminista. Con esto no quiero decir que todos los planteamientos desde los feminismos estén de acuerdo con lo que yo expongo. Como he comentado tanto en mi autoetnografía como en el capítulo uno en referencia a los debates sobre la pornografía, existen muchos feminismos y no tienen por qué compartir las mismas ideas e incluso pueden estar enfrentadas entre ellas. En esta tesina planteo una opción de ver el Hentai desde otra óptica sin pretender que sea la única óptica feminista.

Por otra parte, me ha sorprendido el no encontrar mucha bibliografía en referencia al Hentai en un contexto europeo. No existen grandes investigaciones al respecto, aunque traten prácticas sexuales en muchos casos transgresoras. Creo necesario que se investigue más este fenómeno, ya que me ha sido muy difícil encontrar bibliografía ya fuera en inglés o en castellano. Pude encontrar alguna en referencia al manga o anime, pero no tanta con respecto al Hentai y menos en lo que hace referencia a los subgéneros de relaciones homosexuales, yaoi y yuri. La misma idea la encuentro en la 
tesis de Kimberly Thompson centrada en la temática yuri, lésbica. (THOMPSON: 2010).

Resaltar también la importancia del contexto cultural en el visionado de estos cómics eróticos. Sobre los referentes culturales hablo más ampliamente en el capítulo dos, sin embargo, comentar que ciertos aspectos entendidos como subversivos desde una perspectiva occidental, como puede ser el travestismo, no se debe a un tipo de subversión sino que forman parte de la cultura japonesa. La cultura nipona no es tan rígida con la dicotomía de género femenino y masculino y lo que se espera de cada quién no está tan estrictamente marcado. (ROBERTSON: 1998) Éste es uno de los motivos por el cuál en el Hentai existe esta flexibilidad con la identidad de género.

Asimismo, haciendo este trabajo final de máster me quedó patente una cosa. Utilizo con mucha frecuencia en mi vida diaria las palabras patriarcado, sexismo, actitudes sexistas, machistas para hacer referencia a determinadas prácticas. Sin embargo, el patriarcado no es un elemento que pueda ser diferenciado de un todo cultural. No es blanco o negro, bueno o malo. Existen micromachismos, existen actitudes sexistas, pero el patriarcado es un todo del que está impregnado este sistema, y es en este todo donde se encuentran grietas por donde se puede romper esta estructura patriarcal. En el caso del Hentai, encontré esas grietas y quise exponerlas aquí. Analizarlas y hacerlas patentes desde el análisis de tres cómics distintos entre ellos pero a la vez con prácticas sexuales que hacían tambalearse muchas ideas tradicionales relacionadas con la sexualidad.

En cuanto a estas prácticas sexuales, leyendo a Jeffrey Weeks en "El malestar de la sexualidad", en la página 339 se pregunta si todos los deseos son igual de válidos. Pensando al respecto, y después de haber analizado estos tres cómics con diferentes fantasías sexuales, mi contestación es que lo son en cuanto a deseos. Cualquier práctica sexual es aceptable en tanto que fantasía. (WEEKS, 1985)

Desde el Hentai se manifiesta cómo en referencia a la sexualidad humana, no existe "lo correcto", "lo natural". Existen distintos deseos y necesidades sexuales dependiendo del personaje. Existen relaciones lésbicas, zoofílicas, sadomasoquistas, intergeneracionales e incluso incestuosas. No se plasman las relaciones "correctas", se plasman todo tipo de fantasías. Se perciben modos alternativos de pensar en nuestras necesidades y deseos eróticos. 
Este trabajo es la forma que yo he encontrado de reivindicar las fantasías sexuales, cualquier fantasía, de masturbarse y disfrutar sin necesidad de otra persona, un acto personal y que empodera, que nos hace dueñas y dueños de nuestro propio cuerpo y placer. Porque como dice Pfil mientras se masturba en el capítulo once: "It feels so good". 


\section{Bibliografía}

- $\quad$ Acebrón, Julian; Merino, Ana (2005) Del fanzine al manga yaoi, lesbianes, gays i transsexuals al còmic. Ajuntament de Lleida: Ámbit de Cultura, Esports i Detrs Civils, ARTimatge S.A.

- $\quad$ Adlys, Tracy (1993) Debating Porn, en Agenda, Violence in Focus, No. 16, pp. 56-61 (Article). Publicado en Agenda Feminist Media

- Allison, Anne (2000) Permitted and prohibited desires: Mothers, comics and censorship in Japan University of California Press, Berkeley and Los Ángeles, California

- Allison, Anne (2006) Millennial monsters: Japanese toys and the global imagination. Berkeley and Los Angeles, University of California Press, Ltd.

- $\quad$ Arroyave, Orlando (2006) Monografías. Casa publicadora Blogger. Obtenido en mayo de 2012 en http://monografiassexualidad.blogspot.com.es/

- Berndt, Jaqueline (1996) El fenómeno manga. Berlín, Ediciones Martínez Roca, S.A.

- $\quad$ Bornstein, Kate (1994) Gender Outlaw. On men, women and the rest of us. Nueva York-Londres, Routledge.

- Bullock, Julia C. (2006) Fantasizing what happens when the goods get together: Female homoeroticism as literary trope en East Asia Cultures Critique Volumen 14 Number 3, pp.663- 685 (Article). Publicado en Duke University Press

- $\quad$ Calderón, Marisa y Osborne, Raquel (eds.) (1990) Mujer, sexo y poder. Aspectos del debate feminista en torno a la sexualidad. Madrid, Instituto de Filosofía, CSIC

- Cameron, Deborah (1990) Discourses of Desire: Liberals, Feminists, and the Politics of Pornography in the 1980s en American Literary History, Vol. 2, No. 4 Winter, pp. 784-798. Publicado en Oxford University Press

- $\quad$ De Bejar, Silvia (2003) Tu sexo es tuyo. Editorial Debolsillo, Barcelona

- Dodson, Betty (1989) Sexo para uno, el placer del autoerotismo. Ediciones Temas de Hoy, Colección Biblioteca Erótica. Obtenido en febrero del 2012 en http://www.nodo50.org/herstory/textos/Dodson, Betty - Sexo para uno.pdf 
- Dolan, Jill (1987) The Dynamics of Desire: Sexuality and Gender in Pornography and Performance en Theatre Journal, Volumen 39, No. 2, pp. 156-174 (Article). Publicado en Johns Hopkins University Press

- Douglas, Mary [1966] Pureza y peligro. Obtenido en abril de 2012 en http://es.scribd.com/doc/15616167/

- $\quad$ Fraiman, Susan (1995) Catharine MacKinnon and the Feminist Porn Debates en American Quarterly, Vol. 47, No. 4, pp. 743-749 (Article). Publicado en The Johns Hopkins University Press

- $\quad$ Foucault, Michael [1977] (1993) Historia de la sexualidad. La voluntad de saber. Madrid, Siglo XXI.

- Garaizábal, Cristina (2009) Debates feministas sobre sexualidad, en Jornadas Feministas 2009, Granada

- $\quad$ Gravett, Paul (2004) Sixty years of Japanese comics. Londres, Laurence King Publishing Ltd

- $\quad$ Guasch, Óscar y Viñuales, Olga (eds.) (2003) Sexualidades : diversidad y control social. Barcelona, Bellaterra.

- Hahn Aquila (2007) Ranma 1/2 Fan Fiction Writers. New Narrative Themes or the same old story? en Mechademia, Volumen 2, pp. 34-47 (Article) Publicado en University of Minnesota Press

- Jimeno Fernández, Enrique Cardedue (2009) De los peligros del amor romántico y las políticas de género. Obtenido en febrero del 2012 en http://www.mujeresnet.info/2009/03/de-los-peligros-del-amor-romantico-y.html

- Lafuente, Isaías (2003) Agrupémonos todas. La lucha de las españolas por la igualdad. Madrid, Editorial Aguilar

- Llopis, María y Bañón, Águeda (s.f.).Girlswholikeporn. Obtenido en 2012 en http://archivo2007.girlswholikeporno.com/manifesto/.

- $\quad$ Llopis, Maria (2010) El postporno era eso. Editorial Melusina, Barcelona

- $\quad$ Lust, Erika (2009) Porno para Mujeres. Editorial Melusina, Barcelona

- MacKinnon, Catherine (1987) Sexualidad. Obtenido en abril del 2012 en http://www.cdh.uchile.cl/Libros/18ensayos/MacKinnon_Sexualidad.pdf. Título original: "Sexuality", capítulo del libro Toward A Feminist Theory of the State, publicado por Harvard University Press, USA (1987), pp. 127 - 154 
- Madrid, Dani; Martínez, Guillermo (2010) El manga i l'animació japonesa. Barcelona, Editorial UOC

- Marqués, Josep Vicent y Osborne, Raquel (1991) Sexualidad y sexismo. Madrid, UNED.

- $\quad$ Martínez, D.P.(2009 ) From Impressionism to Anime: Japan as Fantasy and Fan cult in the mind of the West en The Journal of Japanese Studies Volumen 35, Number 1, pp. 120- 124 35. Publicado en Society for Japanese Studies

- $\quad$ McLelland, Mark (2006) A Short History of Hentai. Obtenido en mayo de 2012 en http://intersections.anu.edu.au/issue12/mclelland.html

- Anónimo (2012) Mi novio me controla lo normal. Blog con autoría no especificada, bajo licencia Move Commons. Obtenido en marzo del 2012 en http://minoviomecontrola.blogspot.com/2010/02/crepusculo -un-amor-peligroso-o$\underline{\text { un.html }}$

- Missé, Miquel y Coll-Planas, Gerard (eds) (2010) El género desordenado: críticas en torno a la patologización de la transexualidad. Barcelona, Egales

- (2008, junio, 12) Mugalari (suplemento cultural del diario Gara). Obtenido en mayo de 2012 en http://ptqk.wordpress.com/2008/07/31/antes-y-despues-del-postporno-annie-sprinkle/

- Nagakubo, Yoko (2005) Yaoi Novels and Shojo Manga (Girls' Comics), in Shojo Manga! Girl Power! Ed Masami Toku, Chico, Calif: Flumem Press

- Napier, Susan J. (2000) Anime, from Akira to Princess Mononoke. Londres, Palgrave.

- $\quad$ Nestle, Joan (1988) A Restricted Country. Londres, Sheba Press.

- Neuschaefer, Hans-Joerg (1994) Adiós a la España eterna : la dialéctica de la censura. Novela, teatro y cine bajo el franquismo. Barcelona, Editorial Anthropos.

- Osborne, Raquel (1989) Las mujeres en la encrucijada de la sexualidad. Barcelona, La Sal.

- $\quad$ Osborne, Raquel (1995) Sexo, género, sexualidad. La pertinencia de un enfoque constructivista en Papers 45 25-31 (Article). Obtenido en 4 de mayo en http://ddd.uab.cat/pub/papers/02102862n45/02102862n45p25.txt

- Papalini, Vanina A. (2006) Mundos tecnológicos, animación japonesa e imaginario social. Buenos Aires, La Crujía ediciones 
- Pérez Sián, María José (2009) Hentai, más allá de la pantalla. Antropología de la imagen y análisis del discurso. Guatemala, C. Obtenido en marzo del 2012 en http://biblioteca.usac.edu.gt/tesis/14/14 0419.pdf

- $\quad$ Philipson, Illene (Autumn, 1984) The Repression of History and Gender: A Critical Perspective on the Feminist Sexuality en Signs, Vol. 10, No. 1 pp. 113-118 (Article). Publicado en University of Chicago Press

- Platero, Raquel (2004) La sexualidad como problema político. Obtenido en febrero del 2012 en http://www.caladona.org/grups/uploads/2007/01/La $\underline{\text { sexualidad_como_problema_politico.pdf }}$

- $\quad$ Prada, Nancy (2009) Fui la puta feliz, la pornógrafa feliz, ya sabéis. Debates feministas sobre la pornografía. Universidad de Cádiz, tesina en máster en género, identidad y ciudadanía 2008 - 2009

- $\quad$ Preciado, Beatriz en el programa "Redes de TV2". Obtenido en febrero del 2012 en https://www.youtube.com/watch?v=W8wfc2JNMd4

- $\quad$ Preciado, Beatriz (2003) Multitudes queer. Notas para una política de los anormales, en Multitudes, $\mathrm{n}^{\circ}$ 12. Obtenido en mayo del 2012 en http://masculinidades.blogspot.com.es/2011/04/multitudes-queer-notas-para-una.html

- $\quad$ Ptqk (2011). Licencia arte libre Obtenido en el blog en mayo de 2012 en http://ptqkblogzine.blogspot.com.es/2008/07/antes-y-despus-del-post-porno-annie.html - $\quad$ Ramírez, Vicente (2005) La biblia de Dragon Ball. Palma de Mallorca, Editorial Dolmen

- $\quad$ Robertson, Jennifer (1998) Takarazuka. Sexual Politics and Popular Culture in modern Japan. Berkeley and Los Angeles, California, University of California Press, Ltd.

- $\quad$ Rubin, Gayle (1986) El tráfico de mujeres: notas sobre la economía política del sexo. Nueva Antropología, 30.

- Rubio, Irene G. (2007, marzo, 1) Nuevos discursos sobre la pornografía. El porno al revés. Diagonal. Obtenido en mayo de 2012 en http://www.diagonalperiodico.net/El-porno-al-reves.html

- $\quad$ Rubio, Irene G. (2007, marzo, 1) Deseos que desbordan el porno convencional. Diagonal. Obtenido en mayo de 2012 en http://www.diagonalperiodico.net/Deseos-quedesbordan-el-porno.html 
- Shamoon. Deborah (2007) Revolutionary Romance: The Rose of Versailles and the transformation of Shojo Manga en Mechademia Volumen 2, pp. 3-17 (Article). Publicado en University of Minnesota Press

- Schodt, Frederik L. (1983) Manga! Manga! The World of Japanese Comics. USA, Kodansha International

- Thompson, Kimberly (2010) Yuri Japanese animation: queer identity and ecofeminism thinking. East Carolina University Thesis in the Faculty of the Department of English. Obtenido en mayo de 2012 en http://thescholarship.ecu.edu/ bitstream/handle/10342/2913/Thompson_ecu_0600M_10210.pdf

- Torres, Diana J. (s.f) Pornoterrorismo. Obtenido en mayo de 2012 en http://pornoterrorismo.com

- Toku, Masami (2007) Shojo Manga! Girls' Comics! A Mirror of Girls' Dreams en Mechademia, Volume 2, pp. 19-32. University of Minnesota Press

- Trujillo, Gracia et al (2005) El eje del mal es heterosexual. Figuraciones, movimientos y prácticas feministas queer. Madrid, Traficantes de sueños

- Vance, Carol S. (1982) Diary of a Conference on Sexuality, Barnard Women's Center

- Vance, Carole (comp.) (1989) Placer y peligro. Explorando la sexualidad femenina. Madrid, Talasa ediciones.

- Weeks, Jeffreys [1985] (1993) El malestar de la sexualidad. Significados, mitos y sexualidades modernas. Madrid, Talasa ediciones.

- Wong, Wendy Siuyi (2006) Globalizing Manga: From Japan to Hong Kong and beyong en Mechademia Volumen 1, pp. 23-45 (Article). Publicado en University of Minnesta Press

- $\quad$ Ziga, Itziar (2009) Devenir perra. Editorial Melusina, Barcelona 